\title{
Brasil: 200 anos de Estado; 200 anos de administração pública; 200 anos de reformas*
}

\author{
Frederico Lustosa da Costa**
}

SumÁrio: 1. Introdução; 2. Administração colonial portuguesa; 3 . A construção do Estado nacional; 4. A República Velha; 5. A "burocratização" do Estado nacional; 6. O nacional desenvolvimentismo; 7. A modernização autoritária; 8. A reforma administrativa da Nova República; 9. A reforma do governo Collor; 10. A reforma Bresser; 11. Considerações finais — síntese histórica.

Summary: 1. Introduction; 2. Colonial Portuguese administration; 3. The construction of the national state; 4. The Old Republic; 5. The "bureacraticization" of the national state; 6. National underdevelopment; 7. An authoritarian modernization; 8. Administrative reform of the New Republic; 9. Reform of the Collor government; 10. Bresser reform; 11. Final remarks — historic synthesis.

Palavras-chave: Estado; administração pública; história administrativa; reforma do Estado; reformas administrativas.

KEY WORDs: state; public administration; administrative history; state reform; administrative reforms.

A passagem dos 200 anos da transferência da corte portuguesa para o Brasil tem suscitado a realização de inúmeros eventos comemorativos, como seminários, palestras, exposições e a publicação de livros e artigos em jornais e revistas. Entretanto, poucos encontros, discussões e publicações em torno dos "200 anos" procuraram destacar a questão da constituição do Estado nacional e da formação da administração pública brasileira. Este artigo preenche uma pequena parte da lacuna deixada na comemoração do bicentenário da chegada da família real portuguesa ao Brasil. Oferece um

\footnotetext{
* Artigo recebido em dez. 2007 e aceito em maio 2008. Nasceu de um dos capítulos da tese de doutoramento em gestão intitulada "Reforma gerencial do Estado no Brasil — condicionantes, estratégias e resultados", defendida junto ao Instituto Superior de Ciências do Trabalho e da Empresa (Iscte), em Lisboa, em junho de 2007.

** Professor titular da Escola Brasileira de Administração Pública e de Empresas (Ebape) da Fundação Getulio Vargas (FGV). Endereço: Praia de Botafogo, 190 - CEP 22250-900, Rio de Janeiro, RJ, Brasil. E-mail: frederico.lustosa@fgv.br
} 
rápido panorama da história das transformações por que tem passado a administração pública brasileira, destacando as mudanças planejadas, quer dizer, os esforços de reforma do aparelho de Estado. São enfatizadas as três grandes reformas que se sucederam a partir de meados dos anos 1930 do século passado, separadas entre si por intervalos de 30 anos - 1937, 1967 e 1995 (ou 1998, ano da promulgação da Emenda Constitucional no 19 ). Todo o percurso percorrido desde 1808 configura hoje uma tríplice efeméride - 200 anos de Estado nacional, 200 anos de administração pública e 200 anos de reformas institucionais e administrativas.

Brazil: 200 years of state; 200 years of public administration; 200 years of reforms

The passing of 200 years since the transfer of the Portuguese Royal Court for Brazil has generated the realization of innumerable commemorative events, such as seminars, guest speakers, expositions and the publication of books and articles in journals and magazines. However, few findings, discussions and publications about the "200 years" looked to examine the question of the constitution of the national state and the formation of Brazilian public administration. This article intends to fill the large void left in the commemoration of the 200 years since the arrival of the Royal Portuguese Family in Brazil. It offers a quick historical panorama of the transformations that Brazilian public administration experienced, emphasizing the planned changes, i.e. the efforts aimed at reforming the state apparatus. Three big reforms are stressed that began in the mid-1930s, separated by intervals of thirty years - 1937, 1967, and 1995 (or 1998, the year of the promulgation of Constitutional Amendment n. 19). The entire trajectory that was initiated in 1808 exhibits today a triple celebration -200 years of national state, 200 years of public administration, and 200 years of institutional and administrative reforms.

\section{Introdução}

A passagem dos 200 anos da chegada da família real portuguesa ao Brasil, em 1808, tem suscitado a realização de inúmeros eventos comemorativos, como seminários, palestras, exposições, e a publicação de muitos livros e artigos em jornais e revistas. A maior parte desses eventos e publicações destaca, em perspectiva histórica, os acontecimentos políticos, as transformações econômicas e o impacto sociocultural da presença da corte na cidade do Rio de Janeiro. Todas as curiosidades estão orientadas para as circunstâncias da partida, da travessia e da chegada - a estratégia; a sofreguidão; a logística; o número de expatriados; os dissabores da viagem e os piolhos da princesa; a passagem por Salvador; a abertura dos portos e os acordos comerciais assimétricos com os ingleses; a instalação da corte e o P. R. ("ponha-se na rua") e todas as boas 
obras do príncipe regente, como a Biblioteca Real, a Imprensa Régia, o Jardim Botânico e tantas outras.

Poucos encontros, discussões e publicações em torno dos "200 anos" procuraram destacar a questão específica da constituição do Estado nacional e da formação da administração pública brasileira. Sabe-se que foi a transferência da família real que criou condições para a emergência do espaço público e a formação da burguesia nacional, tornando impossível a restauração da situação colonial anterior e favorecendo a independência nacional. Foi a instalação da corte que transformou uma constelação caótica de organismos superpostos em um aparelho de Estado. Pois o Estado representado pela administração colonial era, ao mesmo tempo, um todo que abrangia o indivíduo em todos os aspectos e uma miríade de instâncias e jurisdições que iam do rei até o mais modesto servidor, cujas atribuições se superpunham, se confundiam e se contradiziam.

É verdade que, até 1808, existia no Brasil e, sobretudo, na sede do governo geral (vice-reino) uma administração colonial relativamente aparelhada. Mas a formação do Reino Unido de Portugal, Brasil e Algarves e a instalação de sua sede na antiga colônia tornaram irreversível a constituição de um novo Estado nacional. Todo um aparato burocrático, transplantado de Lisboa ou formado aqui, em paralelo à antiga administração metropolitana, teve que ser montado para que a soberania se afirmasse, o Estado se constituísse e se projetasse sobre o território, e o governo pudesse tomar decisões, ditar políticas e agir.

Este artigo preenche uma pequena parte da lacuna deixada na comemoração do bicentenário da chegada da família real portuguesa ao Brasil. Oferece um rápido panorama da história das transformações por que tem passado a administração pública brasileira, destacando as mudanças planejadas, quer dizer, os esforços de reforma do aparelho de Estado. São enfatizadas três grandes reformas que se sucederam a partir de meados dos anos 1930, separadas entre si por intervalos de 30 anos - 1937, 1967 e 1995 (ou 1998, ano da promulgação da Emenda Constitucional no 19). De qualquer maneira, todo o percurso percorrido desde 1808 configura hoje uma tríplice efeméride - 200 anos de Estado nacional, 200 anos de administração pública e 200 anos de reformas institucionais e administrativas.

Parte-se do pressuposto de que não é possível entender as recentes transformações do Estado, da organização governamental e da administração pública brasileira sem tentar reconstruir os processos de formação e diferenciação histórica do aparato estatal que se constituiu no Brasil, desde que a empresa da colonização aqui aportou, no alvorecer do século XVI, ou, pelo 
menos, desde que o príncipe regente dom João VI transferiu a sede da Coroa portuguesa para o Rio de Janeiro e instituiu o Reino Unido de Portugal, Brasil e Algarves.

\section{Administração colonial portuguesa}

Tomar o desembarque da Coroa portuguesa no Rio de Janeiro, em 1808, como marco para a construção do Estado nacional não significa dizer que nada existisse em termos de aparato institucional e administrativo. Havia na colônia uma ampla, complexa e ramificada administração. Caio Prado Júnior (1979:299-300) adverte que, para compreendê-la, é preciso se desfazer de noções contemporâneas de Estado, esferas pública e privada, níveis de governo e poderes distintos. A administração colonial, apesar da abrangência das suas atribuições e da profusão de cargos e instâncias, do ponto de vista funcional, pouco se diferencia internamente. Tratava-se de um cipoal de ordenamentos gerais, encargos, atribuições, circunscrições, disposições particulares e missões extraordinárias que não obedeciam a princípios uniformes de divisão de trabalho, simetria e hierarquia. O caos legislativo fazia surgir num lugar funções que não existiam em outros; competências a serem dadas a um servidor quando já pertenciam a terceiros; subordinações diretas que subvertiam a hierarquia e minavam a autoridade.

Em princípio, a administração colonial estava organizada em quatro níveis - as instituições metropolitanas, a administração central, a administração regional e a administração local. Essa estrutura tinha em seu topo o Conselho Ultramarino, subordinado ao secretário de Estado dos Negócios da Marinha e Territórios Ultramarinos que se ocupava de todos os aspectos da vida das colônias, à exceção dos assuntos eclesiásticos, a cargo da Mesa de Consciência e Ordens.

Do ponto de vista da organização territorial, o Brasil estava dividido em capitanias, que eram as maiores unidades administrativas da colônia. O território delas era dividido em comarcas que, por sua vez, era composto por termos sediados nas cidades ou vilas. Os termos eram constituídos de freguesias que correspondiam às paróquias da circunscrição eclesiástica. Por último, as freguesias se dividiam em bairros, cuja jurisdição era imprecisa (Caio Prado Junior, 1979:306).

Desde o início da colonização, com o fracasso da administração privada da maioria das capitanias hereditárias, a Coroa portuguesa assumiu diretamente o seu controle e preocupou-se em instituir uma administração central 
para se ocupar das questões de defesa contra os ataques dos invasores e dos índios mais belicosos. Foi assim que constituiu o governo geral, em 1549, na Bahia, que muito mais tarde, já no Rio de Janeiro, viria a ser o vice-reino. Embora o vice-rei tivesse maior proeminência sobre os demais governadores, seu poder era limitado, nada mandava da Bahia para o norte e tampouco ao sul de São Paulo.

O chefe supremo da capitania era o governador ou capitão-general ou ainda capitão-mor. O governador do Rio de Janeiro também era chamado de vice-rei. Havia capitanias gerais ${ }^{1}$ e subalternas ${ }^{2}$ sendo que os governadores das primeiras exerciam atribuições semelhantes às do vice-rei e havia mesmo alguns que reivindicavam esse tratamento. A função de governador era, sobretudo, militar, mas sua autoridade superintendia toda a administração. Seu poder era grande, mas limitado por normas restritas ditadas pelo Conselho Ultramarino. Ademais, sua influência era contrabalançada pela autoridade das relações, entidades de natureza judiciária e administrativa das quais os governadores eram membros, entre outros, e dos demais órgãos setoriais como as intendências do ouro e dos diamantes e as mesas de inspeção. Ainda assim, era amplo o seu poder e variada a sua competência. Sua autoridade era real e simbólica, pois encarnava a figura do próprio rei. Sob sua supervisão encontravam-se os setores da administração geral, militar e fazendária.

A administração militar estava dividida em tropa de linha, milícias e corpos de ordenança. A primeira era a tropa regular e profissional, formada por regimentos permanentemente armados. As milícias eram tropas auxiliares de cidadãos recrutados obrigatoriamente, sem remuneração, e organizadas em regimentos. As ordenanças constituíam a terceira linha, formada por toda a população masculina com idade entre 18 e 60 anos, não alistada na tropa regular ou nas milícias.

A administração geral contemplava tanto a esfera propriamente administrativa quanto a judiciária, com sua complexa distribuição de encargos, sujeita a superposições e conflitos de competência. Os juízes tinham funções judiciais e administrativas, julgando e executando ao mesmo tempo. A administração geral às vezes se confundia com a administração local. As câmaras exerciam funções legislativas, executivas e judiciárias. Seu senado era presidi-

\footnotetext{
${ }^{1}$ Bahia, Pernambuco, Minas Gerais, São Paulo, Pará, Maranhão, Goiás e Mato Grosso.

${ }^{2}$ São José do Rio Negro, Piauí, Ceará, Rio Grande do Norte, Paraíba, Espírito Santo, Rio Grande de São Pedro e Santa Catarina. As capitanias do Ceará e da Paraíba tornaram-se autônomas em 1799 e do Rio Grande de São Pedro em 1802.
} 
do por um juiz letrado, ou juiz-de-fora, ou por um juiz leigo, o juiz ordinário. Além do juiz, o senado era formado por três vereadores e um procurador, todos sem remuneração e reunindo-se duas vezes por semana em "vereança" ou "vereação".

A administração fazendária, encarregada de arrecadar os tributos, realizar despesas e gerir o Real Erário nas capitanias, estava sob a direção de uma Junta da Fazenda, presidida pelo governador. Paralela ou complementarmente atuavam também as Juntas de Arrecadação do Subsídio Voluntário à Alfândega, o Tribunal da Provedoria da Fazenda, além dos órgãos que exerciam funções judiciárias e administrativas — o Juízo da Conservatória, Juízo da Coroa e Execuções, Juízo do Fisco, das Despesas etc. O principal tributo era o dízimo e sua arrecadação, como a dos demais (direitos de alfândega, passagens, entradas, imposições especiais, donativos e emolumentos), se fazia por contrato, entregando-se a particulares, por prazo determinado, a cobrança.

Além desses três grandes setores, havia ainda órgãos especiais como a Administração dos Índios, a Intendência do Ouro e dos Diamantes, a Intendência da Marinha, a Mesa de Inspeção, as Conservatórias de Cortes de Madeira, alguns já referidos, e toda a Administração Eclesiástica, que também exercia funções civis.

A síntese histórica de Caio Prado Júnior, retomada por Arno e Maria José Wehling (1999), aponta como principais características da administração colonial - a centralização, a ausência de diferenciação (de funções), o mimetismo, a profusão e minudência das normas, o formalismo e a morosidade. Essas disfunções decorrem, em grande medida, da transplantação para a colônia das instituições existentes na metrópole e do vazio de autoridade (e de obediência) no imenso território, constituindo um organismo autoritário, complexo, frágil e ineficaz.

Isso não quer dizer que não tenha havido um processo de gradual racionalização do governo colonial ao longo de três séculos. A partir da administração pombalina, pouco a pouco, o empirismo paternalista do absolutismo tradicional foi sendo substituído pelo racionalismo típico do despotismo esclarecido. Essa mudança se expressava principalmente nos métodos e processos de trabalho que davam lugar à emergência de uma burocracia.

A centralização de decisões na Coroa portuguesa, aparentemente, esvaziava o poder dos governadores e juízes. Tudo era prescrito em regulamentos circunstanciados e nada se excluía da alçada de competência de uma autoridade superior que poderia decidir em primeira instância ou em grau de recurso. Mas a enorme distância da sede do poder e a lentidão na troca de mensagens criavam um vazio de autoridade legal. Tentava-se limitar a ação dos prepostos 
da Coroa com a minudência dos regulamentos que eram repetitivos, superpostos, contraditórios e confusos. Como estatuíam instituições simétricas às da administração da metrópole, pecavam pelo artificialismo mimético que tornava as normas supérfluas e ineficazes. O formalismo das regras, o braço curto da autoridade e a corrupção generalizada ensejavam o autoritarismo daqueles que deviam se impor aos súditos entregues ao abandono, com os próprios meios que deles conseguissem extrair.

\section{A construção do Estado nacional}

A transferência da família real portuguesa para o Brasil deu-se de forma confusa. Até o último instante, o príncipe regente hesitou em partir diante da remota possibilidade de os franceses aceitarem mais um suborno. Só se decidiu quando as tropas de Junot já se encontravam em solo português, às portas de Lisboa. O alvoroço descrito por alguns dos relatos dos momentos que antecederam a longa travessia não condiz com o minucioso planejamento que a inédita mudança de uma corte para outro continente deveria merecer (Wilcken, 2005:35-38). Em primeiro lugar, a própria escolha das cinco, 10 ou 15 mil pessoas — os números são imprecisos — que comporiam a lotação das naus, diz alguma coisa sobre as instituições e espaços de poder que estavam sendo transplantados. Em segundo lugar, a seleção dos bens que era possível carregar, além dos tesouros e objetos de indiscutível valor, contemplava material, livros, papéis, artefatos, instrumentos e símbolos necessários à administração. Em terceiro lugar, a instituição de um simulacro de governo em solo europeu, que se deu na forma de uma regência, logo destituída pelo ocupante.

Todo o acervo administrativo estava a bordo: arquivos, documentos e papéis de governo, e de tal maneira arranjados que, ao desembarcarem no Rio de Janeiro, nenhuma falta ou dificuldade especial se fez sentir, e a faina de dirigir a monarquia continuou no novo continente tão normalmente como se estivera o regente em Lisboa. Que melhor prova exigir da previsão, do longo preparo, e da observância das ordens mais minudentes para organizar o plano de transferência (Calógeras, 1980:59)?

As condições da chegada também são indicativas da possibilidade de constituição do aparato administrativo, militar, protocolar e simbólico de uma corte européia. O primeiro problema era de edificações para acolher as residências da nobreza exilada e as novas repartições do reino. Isso se fez desalojando os prepostos da Coroa, os poucos fidalgos e os ricos comerciantes 
que cederam suas casas e palacetes. Por outro lado, acentuou-se a tendência patrimonialista de reunir no mesmo edifício o domicílio e o local de trabalho.

O regente chegou ao Rio de Janeiro com um governo formado pelos ministérios do Reino ou dos Negócios do Reino, cujo titular atuava também como ministro assistente ao despacho do gabinete e como presidente do Erário Real; da Guerra e Estrangeiros (ou dos Negócios da Guerra e Estrangeiros) e da Marinha (ou dos Negócios da Marinha) e Domínios Ultramarinos; ou seja, três ministros para seis pastas. Três dias depois de sua chegada, substituiu os ministros.

A instalação da corte ensejou a criação de uma série de organismos que existiam na antiga sede do Reino, alguns deles não tão necessários quanto outros. O governo arranjado de acordo com o Almanaque de Lisboa dava oportunidade de criar cargos e honrarias para tantos que haviam feito o sacrifício de acompanhar sua alteza real. Assim, criaram-se o Desembargo do Paço, o Conselho de Fazenda e a Junta de Comércio, quando o país precisava, segundo Hipólito da Costa, de "um conselho de minas, de uma inspeção para abertura de estradas, uma redação de mapas, um exame da navegação dos rios" (Vinhosa, 1984:167). Mas cuidou também o governo de criar instituições e organismos úteis e necessários, como a Academia de Marinha, a de Artilharia e Fortificações, o Arquivo Militar, a Tipografia Régia, a Fábrica de Pólvora, o Jardim Botânico, a Biblioteca Nacional, a Academia de Belas Artes, o Banco do Brasil e os estabelecimentos ferríferos de Ipanema. São muitas as criações e inovações institucionais, jurídicas e administrativas que tiveram largo impacto na vida econômica, social, política e cultural do Brasil, tanto no plano nacional, quanto na esfera regional. São leis, cidades, indústrias, estradas, edificações, impostos, cadeias, festas e costumes que foram introduzidos no pacato cotidiano da antiga colônia.

O fato é que a transferência da corte e mais tarde a elevação do Brasil a parte integrante do Reino Unido de Portugal constituíram as bases do Estado nacional, com todo o aparato necessário à afirmação da soberania e ao funcionamento do autogoverno. A elevação à condição de corte de um império transcontinental fez da nova administração brasileira, agora devidamente aparelhada, a expressão do poder de um Estado nacional que jamais poderia voltar a constituir-se em mera subsidiária de uma metrópole de além-mar.

Com a derrocada de Napoleão I, a reorganização geopolítica da Europa e as agitações dos liberais no Porto, em 1821, d. João VI teve que retornar a Portugal e reassumir o controle político da metrópole. Ficaram no Brasil o príncipe herdeiro, na condição de regente dessa parte do Reino, e todo o aparato administrativo instalado pelo rei. D. Pedro I nomeou seu próprio mi- 
nistério. Transferiu a pasta dos Negócios Estrangeiros da Secretaria da Guerra, para o Ministério do Reino, dando ainda mais relevância a esse ministro. Mas era o próprio príncipe a maior autoridade do Brasil, que a exercia com vigor, impetuosidade e, por vezes, intemperança, colocando-se no centro das disputas políticas locais e no contraponto dos interesses da metrópole.

Os conflitos em matéria fiscal, as propostas em discussão nas cortes para a retomada da condição colonial do Brasil e a exigência do retorno do príncipe a Lisboa colocaram-no em franca oposição aos interesses da metrópole, ensejando a realização de uma seqüência de atos políticos de peso que culminaram com a independência, pouco mais de um ano depois da partida de d. João VI. A sete de setembro de 1822, d. Pedro I declarou a independência e instituiu o governo do Brasil, valendo-se do aparato da regência do Reino Unido que se partia. Não convém nos alongarmos aqui sobre as peripécias relacionadas com a constituição (política) do governo, o enfrentamento das resistências à independência, a convocação, instalação, atuação e dissolução da Assembléia Constituinte e a outorga da Constituição de 1824.

O fato é que, dissolvida a Assembléia Constituinte, o príncipe criou um Conselho de Estado e a ele encomendou a redação da Carta que outorgou ao país em 25 de março de 1824. A primeira Constituição do Brasil mantinha a monarquia, a dinastia da Casa de Orléans e Bragança e d. Pedro I como imperador e defensor perpétuo do Brasil. Constituía um Estado unitário e centralizador, cujo território era dividido em províncias, que substituíam as antigas capitanias. Os poderes políticos eram quatro - Legislativo, Moderador, Executivo e Judicial. Cada província era dirigida por um presidente nomeado pelo imperador, que tomava posse perante a câmara da capital. Em cada uma delas havia também um conselho geral, cujos membros eram eleitos juntamente com a representação nacional. O monarca exercia o Poder Moderador, com o apoio do Conselho de Estado, órgão de caráter consultivo e, ao mesmo tempo, o Poder Executivo, auxiliado pelos seus ministros de Estado. O Poder Legislativo era exercido pela Assembléia Geral, formada pela Câmara dos Deputados e pela Câmara dos Senadores ou Senado do império. O Poder Judicial era exercido pelos juízes de direito e pelos juízes de paz, para as tentativas de conciliação prévias a qualquer processo. Na capital do império e nas províncias havia um Supremo Tribunal de Justiça, composto de juízes letrados tirados das relações. A organização dos municípios não mudou de forma significativa, tendo as câmaras o mesmo papel que exerciam na colônia.

Depois de 10 anos à frente do destino do Brasil, d. Pedro I abdicou do trono em favor de seu filho Pedro II, então com apenas cinco anos de idade. Deixou o governo em meio a uma crise de grandes proporções, gerada por 
problemas financeiros, revoltas regionais, identificação com os interesses portugueses e queda de braço com o Legislativo. Conforme previa a Constituição, assumiu uma Regência Trina que enfrentou, assim como as que lhe sucederam, uma série de crises que terminaram por ensejar, em 1841, a declaração da maioridade do imperador menino, aos 15 anos de idade. Logo no início do período regencial, em 1832, foi feita uma reforma constitucional, que instituiu a Regência Una, aboliu o Conselho de Estado e criou as assembléias legislativas provinciais, em substituição aos conselhos gerais. Tratava-se de pequeno passo no sentido da descentralização, uma vez que instituía o Poder Legislativo provincial e a divisão de rendas entre o governo central e os governos provinciais.

Outra mudança constitucional importante, já em 1847, foi a criação do cargo de presidente do conselho de ministros que, na prática, significou a instituição do regime de gabinete, conferindo maior estabilidade ao governo imperial. O imperador passou a concentrar-se no exercício do Poder Moderador, embora não se eximisse de participar da escolha dos gabinetes, chegando mesmo a designar um governo que não tinha maioria na câmara. Num e noutro caso, tratava-se de arbitrar os conflitos entre frações das classes dominantes e sustentar a ordem monárquica, apoiada na grande propriedade rural, na economia primário-exportadora e no trabalho escravo em declínio.

Nos 10 últimos anos do Império, esses conflitos tornaram-se mais agudos, exercendo forte pressão sobre o governo. Em primeiro lugar, a questão do trabalho escravo colocava, de um lado, grandes proprietários de terra e, de outro, os setores urbanos, adeptos do abolicionismo. Sua libertação suprimiu uma das bases de sustentação da ordem imperial. Em segundo lugar, o problema da autonomia das províncias contrapunha os centralizadores e os partidários da descentralização. Em terceiro lugar, a Guerra do Paraguai trouxe como conseqüência o desequilíbrio das finanças públicas, o fortalecimento do papel político do Exército e a exposição da contraditória condição do soldado escravo, contribuindo para desestabilizar ainda mais o governo. Por último, o precário estado de saúde do imperador, muito querido pelos súditos de todas as classes, colocava em primeiro plano a questão sucessória e a ameaça de que o país viesse a ser governado com o concurso de um estrangeiro, o conde D’Eu, marido da princesa Isabel, extremamente antipatizado.

Nesse ambiente político, germinava um incipiente movimento republicano, apoiado num vago programa de reformas que tentava conciliar interesses opostos de monarquistas liberais e de escravocratas descontentes com a política abolicionista do Império. O movimento republicano se dividia em dois pólos - o federalismo e o liberalismo. O primeiro era protagonizado pelas 
lideranças políticas de São Paulo e do Rio Grande do Sul e o segundo representado pelos políticos da cidade do Rio de Janeiro. Os republicanos do Rio de Janeiro defendiam a participação política da população e os gaúchos e paulistas partidários do federalismo pregavam uma maior autonomia regional. As críticas mais comuns recaíam sobre a centralização excessiva do regime monárquico, que restringia a liberdade política e econômica das províncias.

Assim, as repetidas crises dos gabinetes imperiais geravam um clima de instabilidade política que dava força ao movimento republicano e à tentação intervencionista do Exército. Pequenos incidentes entre líderes militares e o governo acabaram dando o último estímulo aos oficiais descontentes para que deflagrassem o golpe de 15 de novembro de 1889. O que houve foi uma marcha de 600 soldados liderados pelo marechal Deodoro da Fonseca contra o quartel-general do Exército, onde estava reunido o ministério.

\section{A República Velha}

A proclamação da República não alterou profundamente as estruturas socioeconômicas do Brasil imperial. A riqueza nacional continuou concentrada na economia agrícola de exportação, baseada na monocultura e no latifúndio. O que se acentuou foi a transferência de seu centro dinâmico para a cafeicultura e a conseqüente mudança no pólo dominante da política brasileira das antigas elites cariocas e nordestinas para os grandes cafeicultores paulistas.

O governo provisório adotou as reformas imediatas necessárias à vigência do novo regime e convocou eleições para uma assembléia constituinte. A Carta de 1891, francamente inspirada na Constituição americana de 1787, consagrou a República, instituiu o federalismo e inaugurou o regime presidencialista. A separação de poderes ficou mais nítida. O Legislativo continuava bicameral, sendo agora formado pela Câmara dos Deputados e pelo Senado, cujos membros passaram a ser eleitos para mandado de duração certa. Ampliou-se a autonomia do Judiciário. Foi criado o Tribunal de Contas para fiscalizar a realização da despesa pública. As províncias, transformadas em estados, cujos presidentes (ou governadores) passaram a ser eleitos, ganharam grande autonomia e substantiva arrecadação própria. Suas assembléias podiam legislar sobre grande número de matérias. Esse sistema caracterizava o federalismo competitivo.

A República federalista, com estados politicamente autônomos, consagrou um novo pacto político que acomodava os interesses das elites econômicas do Centro-Sul e do resto do país. O governo federal ocupava-se de 
assegurar a defesa e a estabilidade e proteger os interesses da agricultura exportadora através do câmbio e da política de estoques, com reduzida interferência nos assuntos "internos" dos demais estados. Lá vicejavam os mandões locais, grandes proprietários de terra e senhores do voto de cabresto, e as grandes oligarquias, que controlavam as eleições e os governos estaduais e asseguravam as maiorias que apoiavam o governo federal. A política dos governadores garantia a alternância na presidência da República de representantes de São Paulo e Minas Gerais. Esse sistema era marcado pela instabilidade dos governos estaduais passíveis de serem derrubados e substituídos em função da emergência de novas oligarquias.

Nesse período, não houve grandes alterações na conformação do Estado nem na estrutura do governo. Desde a proclamação da República, a principal mudança no Poder Executivo foi a criação dos ministérios da Instrução Pública, de brevíssima existência; da Viação e Obras Públicas; e da Agricultura, Indústria e Comércio, cujos nomes sofreram pequenas modificações. Do ponto de vista da federação, houve uma ligeira redução na capacidade legislativa dos estados, que perderam o poder de legislar sobre determinadas matérias.

A República Velha durou cerca de 40 anos. Aos poucos, foi se tornando disfuncional ao Brasil que se transformava, pela diversificação da economia, pelo primeiro ciclo de industrialização, pela urbanização e pela organização política das camadas urbanas. Novos conflitos de interesse dentro dos setores dominantes, entre as classes sociais e entre as regiões punham em causa o pacto oligárquico, as eleições de bico de pena $^{3}$ e a política do café-com-leite. ${ }^{4}$ Por outro lado, desde a guerra contra o Paraguai (1864-70), o Exército passou a ser um ator político cada vez mais importante, como arena de revoltas ou sujeito de ações determinantes, perseguindo ideais modernizadores ou salvacionistas.

A eleição do paulista Júlio Prestes para suceder o também paulista Washington Luís, derrotando o gaúcho Getúlio Vargas, desencadeou o rompimento do pacto com os mineiros e com as demais oligarquias estaduais, abrindo espaço para mais uma intervenção do Exército — a Revolução de 1930.

\footnotetext{
${ }^{3}$ Assim eram chamadas as eleições que então se realizavam, cujos resultados favoráveis às oligarquias dominantes eram ajustados nos mapas eleitorais, ao bico da pena.

${ }^{4}$ A expressão refere-se à alternância na presidência da República de políticos originários de São Paulo, grande produtor de café, e de Minas Gerais, principal produtor de leite.
} 


\section{A "burocratização" do Estado nacional}

A narrativa precedente dá conta do processo de formação do Estado nacional, a partir de suas raízes coloniais, ao longo do Império (1882-89) e da chamada República Velha (1889-1930). Embora seja desse período a cristalização das principais características do Estado brasileiro apontadas anteriormente, observa-se que a própria diferenciação do aparelho de Estado e a criação de novas instituições fazem parte da dinâmica de instauração da modernidade. Estado e mercado, autônomos com relação à ordem do sagrado e à dominação patriarcal e cada vez mais separados entre si, constituem as bases da formação social moderna. Seu desenvolvimento, consideradas as características do contexto local, se dá no sentido da racionalização. A burocracia está no horizonte da administração pública que se consolida e atualiza. Se esse movimento se deu de forma lenta e superficial nos primeiros 100 anos de história do Brasil independente, ele vai encontrar seu ponto de inflexão e aceleração na Revolução de 1930.

De fato, a partir desse marco e durante a maior parte do século $\mathrm{XX}$, o Brasil empreendeu um continuado processo de modernização das estruturas e processos do aparelho de Estado. Como resposta a transformações econômicas e sociais de largo alcance, esse esforço se desenvolveu ora de forma assistemática, pelo surgimento de agências governamentais que se pretendia fossem ilhas de excelência com efeitos multiplicadores sobre as demais, ora de forma mais orgânica, por meio das reformas realizadas no governo federal, em 1938, 1967 e a partir de 1995.

A chamada "Revolução de 1930" representou muito mais do que a tomada do poder por novos grupos oligárquicos, com o enfraquecimento das elites agrárias. Significou, na verdade, a passagem do Brasil agrário para o Brasil industrial. Para compreender essa transformação e a emergência do modelo de crescimento que presidiu o desenvolvimento nacional no século XX, é preciso entender como se dava a inserção do país na economia internacional e como o Brasil viveu a Grande Depressão.

Como foi dito, o Brasil era uma economia periférica apoiada na exportação de produtos primários entre os quais se destacava o café, principal item da pauta de exportações. O lucro dessa monocultura permitiu financiar o primeiro ciclo de industrialização brasileira, concentrando-se em São Paulo, pólo da cafeicultura. Os interesses dos produtores de café eram protegidos pelo governo federal, com políticas de câmbio favorável e formação de estoques reguladores. Com a crise de 1929, que penalizou os mercados consumidores, o Brasil foi obrigado a reduzir a exportação de café, ficando sem divisas para 
manter a importação de produtos industrializados. O governo federal, entretanto, continuou comprando, embora a preços reduzidos, o excedente de café não-exportável, formando estoques que não conseguia comercializar. Conforme os estoques envelheciam, o café era queimado para dar lugar à aquisição de novas safras. Essa política mantinha um fluxo de renda para o setor mais dinâmico da economia, evitando o desemprego no campo e a recessão generalizada. Por outro lado, a impossibilidade de continuar importando para satisfazer a demanda por produtos industrializados estimulou uma série de iniciativas de produção industrial para substituir bens importados. Praticava-se assim, de forma intuitiva, uma política keynesiana, onde o Estado exercia um papel fundamental na manutenção da demanda agregada, pela transferência de rendas para os trabalhadores-consumidores, e estimulava a substituição de importações.

Esse comportamento ensejou mais tarde uma reflexão sobre o desenvolvimento econômico na América Latina. De um lado, passou-se a propugnar uma política de crescimento baseada na industrialização via substituição de importações, reduzindo a dependência das economias primário-exportadoras, sujeitas à crescente desvalorização de seus produtos. De outro, o sucesso do New Deal, política de intervenção do Estado na economia americana para recuperar sua dinâmica de crescimento, levava a pensar que ela também seria possível e desejável para promover o crescimento das economias periféricas. O Estado nacional poderia liderar o processo de desenvolvimento, estabelecendo barreiras alfandegárias, construindo infra-estruturas, criando subsídios e incentivos e oferecendo crédito. Esse papel supunha não só a capacidade de gerar poupança interna para participar da formação bruta de capital como também um elevado grau de intervenção na economia, em particular, e na vida social em geral. Estavam lançadas as bases do modelo de crescimento e do Estado intervencionista brasileiro.

Do ponto de vista político, havia um quadro favorável à transformação do Estado para atender às novas exigências do seu papel de indutor do desenvolvimento. As elites oligárquicas excluídas do compromisso do antigo regime uniram-se às forças emergentes representativas da nova burguesia industrial e das camadas médias urbanas. O movimento revolucionário também teve o apoio dos "tenentes", lideranças militares egressas da revolta de 1922, comprometidos com um projeto de reformas modernizadoras (e autoritárias). ${ }^{5}$

\footnotetext{
${ }^{5}$ Uma revolta de jovens oficiais no Rio de Janeiro deu origem ao movimento militar denominado tenentismo que, por um ideário nacionalista, modernizador e autoritário, interferiu na política
} 
O primeiro período de Vargas na presidência durou 15 anos, sendo quatro de governo provisório, três de governo constitucional e oito de ditadura. No período inicial, houve uma grande concentração de poderes nas mãos do Executivo federal, em conseqüência da dissolução dos corpos legislativos e da nomeação de interventores para os governos estaduais. Como marco da incorporação de novos atores sociais, foi criado o Ministério do Trabalho, Indústria e Comércio, que estabelecia uma interlocução com esses setores e lançava as bases do pacto corporativista que se seguiria. Os "tenentes" foram absorvidos em diversas posições de governo, alguns inclusive como interventores nos estados, trazendo suas idéias e a marca da ruptura com o velho pacto oligárquico. Mas o governo manteve a política de valorização do café e procurou contemporizar com as oligarquias que aderiram ao movimento revolucionário. Embora tenha contribuído para a ampliação e consolidação da burguesia industrial, essa foi a imagem bifronte da política de Vargas - uma face voltada para as oligarquias rurais e outra para as massas urbanas.

A centralização e a suspensão das franquias constitucionais geraram crescente insatisfação em setores liberais, sobretudo em São Paulo, desencadeando uma série de revoltas, entre as quais a Revolução de 1932 que, depois de sufocada, ensejou a convocação de uma Constituinte e, em seguida, a promulgação da Constituição de 1934.

A Constituição de 1934 restabeleceu os direitos e garantias dos cidadãos, restaurou o Poder Legislativo e devolveu a autonomia dos estados. Não consentiu a volta dos mesmos níveis de descentralização que vigoravam na República Velha. Na repartição de encargos e recursos, concentrou competências no nível da União. Promoveu a uniformização das denominações dos cargos de governador e prefeito e fixou limites para a organização e as atribuições dos legislativos estaduais. Inaugurou o federalismo cooperativo, com a repartição dos tributos, beneficiando inclusive os municípios, e a coordenação de ações entre as três esferas de governo.

A nova Constituição teve vida muito breve. Enfrentando a oposição político-partidária e a ação organizada do movimento integralista e a ação revolucionária dos comunistas, o governo encontrou o pretexto de que precisava para desfechar um golpe de Estado que se deu em novembro de 1937, instituindo o chamado Estado Novo. A ditadura fechou o Congresso Nacional e as assembléias legislativas, suspendeu as garantias constitucionais, destituiu os

brasileira em diversos momentos, tendo papel importante na Revolução de 1930 e no longo primeiro período presidencial de Getúlio Vargas. 
governadores eleitos, centralizou recursos, aboliu as bandeiras e os hinos estaduais, prendeu e perseguiu adversários e oposicionistas e outorgou uma nova constituição, a dita polaca. A centralização passa a constituir um princípio de organização do Estado brasileiro que se aplica de forma sistemática em todos os setores e níveis de estruturação territorial.

Mantendo a política de proteção às matérias-primas exportadas, o governo lançou-se de maneira franca e direta no projeto desenvolvimentista, criando as bases necessárias da industrialização - a infra-estrutura de transporte, a oferta de energia elétrica e a produção de aço, matéria-prima básica para a indústria de bens duráveis. Mais do que isso, assumiu papel estratégico na coordenação de decisões econômicas. Para tanto, teve que aparelhar-se. As velhas estruturas do Estado oligárquico, corroídas pelos vícios do patrimonialismo, já não se prestavam às novas formas de intervenção no domínio econômico, na vida social e no espaço político remanescente. Urgia reformar o Estado, o governo e a administração pública.

Assim, sob o impulso de superação do esquema clientelista e anárquico de administração oligárquica, o governo de Getúlio Vargas iniciou uma série de mudanças que tinham pelo menos duas vertentes principais (Lima Junior, 1998): ${ }^{6}$

v estabelecer mecanismos de controle da crise econômica, resultante dos efeitos da Grande Depressão, iniciada em 1929, e subsidiariamente promover uma alavancagem industrial;

- promover a racionalização burocrática do serviço público, por meio da padronização, normatização e implantação de mecanismos de controle, notadamente nas áreas de pessoal, material e finanças.

A partir de 1937, promoveu uma série de transformações no aparelho de Estado, tanto na morfologia, quanto na dinâmica de funcionamento. Nesse período foram criados inúmeros organismos especializados e empresas estatais. "Até 1939, haviam sido criadas 35 agências estatais; entre 1940 e 1945 surgiram 21 agências, englobando empresas públicas, sociedades de economia mista e fundações" (Lima Júnior, 1998:8). Até 1930 existiam no Brasil 12 empresas públicas; de 1930 a 1945, foram criadas 13 novas empresas, sendo 10 do setor produtivo, entre elas a Companhia Vale do Rio Doce, hoje

\footnotetext{
${ }^{6}$ Baseio neste artigo boa parte da descrição que se segue sobre os esforços para a reforma administrativa no Brasil.
} 
uma gigante da mineração, e a Companhia Siderúrgica Nacional, ambas já privatizadas.

Desde o início do governo provisório, foram tomadas medidas visando à racionalização dos procedimentos. Já no discurso de posse do presidente Vargas, ao apresentar sua plataforma de governo, ele se propunha a promover uma série de reformas, entre elas a criação de um Ministério de Instrução e Saúde Pública; a remodelação do Exército e da Armada; a reorganização do aparelho judiciário; a "consolidação das normas administrativas, com o intuito de simplificar a confusa e complicada legislação vigorante, bem como de refundir os quadros do funcionalismo, que deverá ser reduzido ao indispensável, suprimindo-se os adidos e os excedentes" (Wahrlich, 1975:7-8); a manutenção de uma administração de rigorosa economia, cortando todas as despesas improdutivas e suntuárias; a reorganização do Ministério da Agricultura; a revisão do sistema tributário; e a instituição do Ministério do Trabalho, "destinado a superintender a questão social, o amparo e a defesa do operariado urbano e rural" (Wahrlich, 1975:7-8).

Dando cumprimento a esse programa, em 1930 foi criada a comissão permanente de padronização e, no ano seguinte, a comissão permanente de compras, ambas voltadas para a aquisição de material. Na área de pessoal, a Constituição de 1934 introduziu o princípio do mérito. Em 1935, foi criada a comissão mista de reforma econômico-financeira, que destacou uma subcomissão, que ficou conhecida como comissão Nabuco, para "estudar a possibilidade de um reajustamento dos quadros do serviço público civil" (Wahrlich, 1975:10). Em decorrência do seu trabalho, em 1936 foi promulgada a Lei no 284, de 28 de outubro, a chamada Lei do Reajustamento, que estabeleceu nova classificação de cargos, fixou normas básicas e criou o Conselho Federal do Serviço Público Civil.

De todas essas medidas, a mais emblemática foi a criação do Departamento Administrativo do Serviço Público, "o líder inconteste da reforma e, em grande parte, seu executor" (Wahrlich, 1974:29). O Dasp foi efetivamente organizado em 1938, com a missão de definir e executar a política para o pessoal civil, inclusive a admissão mediante concurso público e a capacitação técnica do funcionalismo, promover a racionalização de métodos no serviço público e elaborar o orçamento da União. O Dasp tinha seções nos estados, com o objetivo de adaptar as normas vindas do governo central às unidades federadas sob intervenção.

Essa primeira experiência de reforma de largo alcance inspirava-se no modelo weberiano de burocracia e tomava como principal referência a organização do serviço civil americano. Estava voltada para a administração de pes- 
soal, de material e do orçamento, para a revisão das estruturas administrativas e para a racionalização dos métodos de trabalho. A ênfase maior era dada à gestão de meios e às atividades de administração em geral, sem se preocupar com a racionalidade das atividades substantivas.

A reforma administrativa do Estado Novo foi, portanto, o primeiro esforço sistemático de superação do patrimonialismo. Foi uma ação deliberada e ambiciosa no sentido da burocratização do Estado brasileiro, que buscava introduzir no aparelho administrativo do país a centralização, a impessoalidade, a hierarquia, o sistema de mérito, a separação entre o público e o privado. Visava constituir uma administração pública mais racional e eficiente, que pudesse assumir seu papel na condução do processo de desenvolvimento, cujo modelo de crescimento, baseado na industrialização via substituição de importações, supunha um forte intervencionismo estatal e controle sobre as relações entre os grupos sociais ascendentes - a nova burguesia industrial e o operariado urbano (Marcelino, 1987).

O Dasp representou a concretização desses princípios, já que se tornou a grande agência de modernização administrativa, encarregada de implementar mudanças, elaborar orçamentos, recrutar e selecionar servidores, treinar o pessoal, racionalizar e normatizar as aquisições e contratos e a gestão do estoque de material. O Dasp foi relativamente bem-sucedido até o início da redemocratização em 1945, quando houve uma série de nomeações sem concurso público para vários organismos públicos. A liberdade concedida às empresas públicas, cujas normas de admissão regulamentadas pelos seus próprios estatutos tornavam facultativa a realização de concursos foi em parte responsável por tais acontecimentos.

Para Beatriz Wahrlich (1984) essas atitudes revelavam que o favoritismo tinha maior peso que as admissões por mérito no sistema brasileiro de administração de pessoal dos órgãos públicos. Contribuíram para isso, "o ambiente cultural encontrado pela reforma modernizadora. (...), o mais adverso possível, corroído e dominado por práticas patrimonialistas amplamente arraigadas" (Torres, 2004:147).

\section{O nacional desenvolvimentismo}

A queda do governo Vargas, além de suas causas mais remotas, foi provocada por mais uma intervenção militar na vida política brasileira. O crescente movimento de oposição ao regime viu-se reforçado pelas lideranças militares recém-saídas da II Guerra Mundial. De fato, parecia contraditório que os 
militares brasileiros voltassem da Europa vitoriosos na luta contra governos totalitários para dar suporte à ditadura.

À falta de lideranças institucionalizadas em posição legítima para assumi-la, a presidência da República foi entregue ao presidente do Supremo Tribunal Federal, que conduziu o governo de transição e convocou as eleições e a Assembléia Nacional Constituinte. A Constituição de 1946 restabeleceu o estado de direito e as garantias individuais, restaurou a divisão de poderes da República, devolveu a autonomia dos estados, ampliou os direitos sociais dos trabalhadores, reorganizou o Judiciário e previu a mudança da capital. Fortaleceu-se o federalismo cooperativo, por meio de novos mecanismos de coordenação e transferência de rendas entre regiões. Eleito em dezembro de 1945, o presidente Dutra, ex-ministro da Guerra de Getúlio Vargas, tomou posse em janeiro do ano seguinte e realizou um governo legalista e conservador, marcado pela dissipação das reservas cambiais acumuladas durante o conflito mundial, pela perda da legalidade do Partido Comunista e pela proibição dos jogos de azar. Durante esse qüinqüênio, foi criada a Companhia Hidrelétrica do São Francisco, aumentando a oferta de energia para o Nordeste do Brasil.

Cinco anos depois de deixar o governo, Getúlio Vargas foi eleito presidente da República, pelo voto direto, em 3 de outubro de 1950. Vargas assumiu o governo, com poderes limitados pela Constituição de 1946, para cumprir um programa francamente nacionalista e reformista, prometendo ampliar os direitos dos trabalhadores e investir na indústria de base e em transportes e energia, o que requeria o aumento da intervenção do Estado no domínio econômico. Nesse período, foram criadas 13 empresas estatais, entre elas a Petrobras e o Banco Nacional de Desenvolvimento Econômico (BNDES), grande pilar da política de fomento da política nacional. Vargas também tentou controlar a remessa de lucros das empresas estrangeiras e criar a Eletrobrás, empresa controladora do setor elétrico. Contra ele insurgiram-se as forças conservadoras ligadas a interesses contrariados, desencadeando acirrada oposição. As pressões aumentaram com a investigação do atentado ao jornalista Carlos Lacerda, perpetrado por membros de sua guarda pessoal, culminando com o ultimato dos chefes militares. Getúlio preferiu a morte à renúncia ou à deposição. Na madrugada do dia 24 de agosto de 1954 desferiu um tiro no peito que o tirou da vida para colocá-lo na história do Brasil, segundo ele mesmo deixou escrito em sua carta-testamento.

Durante o segundo governo Vargas também se pretendeu retomar os esforços reformistas pela designação, em 1952, de um grupo de trabalho com a missão de elaborar um projeto de reforma administrativa que resultou num projeto de lei que previa a reorganização administrativa do ministério e a 
alteração do código de contabilidade das despesas públicas, abolindo o registro prévio. Submetida ao Congresso Nacional, mereceu um substitutivo de comissão interpartidária que previa a criação do Conselho de Planejamento e Coordenação e dos ministérios do Interior e das Comunicações e Transportes, que não chegou a ser aprovado, não obstante o apoio do Executivo.

Depois de um tumultuado período de transição de mais de um ano, com golpes, contragolpes, a eleição e a tentativa de impedimento da posse do eleito, assumiu o governo em 1956, Juscelino Kubitscheck de Oliveira. Seu Plano de Metas tinha 36 objetivos, com destaque para quatro setores-chave: energia, transporte, indústria pesada e alimentação. Propugnava a industrialização acelerada, apoiada na associação entre capitais nacionais e estrangeiros, com ênfase na indústria de bens duráveis, dando prioridade à indústria automobilística e ao transporte rodoviário. Seu lema era a realização de "50 anos em cinco" e a meta símbolo era a construção da nova capital do país, Brasília (Mendonça, 1990:335). Era uma fase de grande euforia e de afirmação nacionalista.

Do ponto de vista institucional, a década que vai de 1952 a 1962 foi marcada pela realização de estudos e projetos que jamais seriam implementados. A criação da Cosb (Comissão de Simplificação Burocrática) e da Cepa (Comissão de Estudos e Projetos Administrativos), em 1956, representa as primeiras tentativas de realizar as chamadas reformas globais. A primeira tinha como objetivo principal promover estudos visando à descentralização dos serviços, por meio da avaliação das atribuições de cada órgão ou instituição e da delegação de competências, com a fixação de sua esfera de responsabilidade e da prestação de contas das autoridades. A Cepa teria a incumbência de assessorar a presidência da República em tudo que se referisse aos projetos de reforma administrativa.

Esse período se caracteriza por uma crescente cisão entre a administração direta, entregue ao clientelismo e submetida, cada vez mais, aos ditames de normas rígidas e controles, e a administração descentralizada (autarquias, empresas, institutos e grupos especiais ad hoc), dotados de maior autonomia gerencial e que podiam recrutar seus quadros sem concursos, preferencialmente entre os formados em think thanks especializados, remunerando-os em termos compatíveis com o mercado. Constituíram-se assim ilhas de excelência no setor público voltadas para a administração do desenvolvimento, enquanto se deteriorava o núcleo central da administração. De acordo com Lima Júnior (1998:10)

a administração do plano de metas foi executada, em grande medida, fora dos órgãos administrativos convencionais. Considerando-se os setores essenciais 
do plano de desenvolvimento (energia, transportes, alimentação, indústrias de base e educação) apenas 5,2\% dos recursos previstos foram alocados na administração direta; o restante foi aplicado por autarquias, sociedades de economia mista, administrações estaduais e empresas privadas. A coordenação política das ações se fazia através dos grupos executivos nomeados diretamente pelo presidente da República.

O governo seguinte ao de Kubitscheck, embora caracterizado por grande agitação política, não produziu transformações de largas conseqüências no aparelho de Estado. Pode parecer até um contra-senso afirmar que a mudança do sistema de governo seja de pouca relevância. Na verdade, a introdução do parlamentarismo depois da renúncia do presidente Jânio Quadros, apenas sete meses depois da sua investidura no cargo, foi uma solução política, de curta duração, para o enfrentamento das resistências militares à posse do vicepresidente João Goulart. O governo instalou-se em meio a uma crise e com ela conviveu durante os 32 meses seguintes. Jango era apoiado pelo Partido Trabalhista Brasileiro e se propunha a realizar um programa de esquerda, orientado para a realização de reformas de base - bancária, fiscal, urbana, agrária, universitária e administrativa. O programa contemplava a extensão do direito de voto aos analfabetos e às patentes. Esse pacote de medidas enfrentava forte oposição dos setores militares que viam na ação política orientada para suboficiais e praças uma grave ameaça à disciplina.

Apesar da crise, o governo Goulart criou a Comissão Amaral Peixoto, que deu início a novos estudos para a realização da reforma administrativa. Seu principal objetivo era promover "uma ampla descentralização administrativa até o nível do guichê, além de ampla delegação de competência" (Marcelino, 1988:41).

Embora tenha havido avanços isolados durante os governos de Getúlio Vargas, Juscelino Kubitschek, Jânio Quadros e João Goulart, o que se observa é a manutenção de práticas clientelistas, que negligenciavam a burocracia existente, além da falta de investimento na sua profissionalização. A cada desafio surgido na administração do setor público, decorrente da própria evolução socioeconômica e política do país, a saída utilizada era sempre a criação de novas estruturas alheias à administração direta e o conseqüente adiamento da difícil tarefa de reformulação e profissionalização da burocracia pública existente (Torres, 2004:151).

Todas as iniciativas anteriormente descritas, como a criação dessas comissões, mesmo que não tenham sido implementadas, não deixaram de inaugurar uma nova visão na administração pública com a introdução de conceitos, diretrizes e objetivos mais racionais, que serviriam de base para futuras 
reformas no aparato administrativo brasileiro. Na verdade, algumas das grandes inovações introduzidas pela reforma de 1967 estavam consignadas nos relatórios da Cosb, da Cepa e, sobretudo, da Comissão Amaral Peixoto, conforme exaustivamente documentado por Beatriz Wahrlich (1974:30-41).

De fato, o ministério extraordinário para a reforma administrativa elaborou quatro projetos que nunca conseguiram aprovação no Congresso, mas alguns especialistas no assunto afirmam que foi a partir deles que se concebeu o Decreto-Lei no 200 , de 1967. Seu estatuto básico prescreve cinco princípios fundamentais:

$\checkmark$ o planejamento (princípio dominante);

v a expansão das empresas estatais (sociedades de economia mista e empresas públicas), bem como de órgãos independentes (fundações públicas) e semi-independentes (autarquias);

v a necessidade de fortalecimento e expansão do sistema do mérito, sobre o qual se estabeleciam diversas regras;

v diretrizes gerais para um novo plano de classificação de cargos;

- o reagrupamento de departamentos, divisões e serviços em 16 ministérios: Justiça, Interior, Relações Exteriores, Agricultura, Indústria e Comércio, Fazenda, Planejamento, Transportes, Minas e Energia, Educação e Cultura, Trabalho, Previdência e Assistência Social, Saúde, Comunicações, Exército, Marinha e Aeronáutica.

\section{A modernização autoritária}

A agitação política provocada pelas reformas de base, a ebulição dos movimentos populares de esquerda, a mobilização da direita católica, a conspiração nos quartéis e as revoltas dos marinheiros e sargentos do Exército acabaram por provocar mais uma intervenção militar que se deu com o golpe de 1을 de abril de 1964. O endurecimento do regime ocorreu aos poucos. Primeiro, a deposição do presidente e de alguns governadores; em seguida, a cassação de mandatos eletivos e a suspensão de direitos políticos; depois, a extinção dos antigos partidos e a suspensão das eleições diretas. Cumpria-se o mesmo programa autoritário de supressão de garantias, cerceamento do Congresso, centralização de decisões, concentração de recursos e esvaziamento da federação.

De certa forma, o governo militar realizou, à sua maneira, com sinais trocados, o programa de reformas de base - elaborou o Estatuto da Terra, 
promoveu uma reforma tributária, reorganizou o sistema bancário, reestruturou o ensino universitário e realizou uma ampla reforma administrativa. Em 1965 teve início a reforma tributária que se consolidou com a Constituição de 1967, uniformizando a legislação, simplificando o sistema e reduzindo o número de impostos. Ela trouxe uma brutal concentração de recursos nas mãos da União, esvaziando financeiramente estados e municípios que ficaram dependentes de transferências voluntárias.

Ainda em 1964, o novo governo retirou do Congresso Nacional o projeto de lei elaborado pela Comissão Amaral Peixoto para reexame do assunto por parte do Poder Executivo. Instituiu a Comestra (Comissão Especial de Estudos da Reforma Administrativa), presidida pelo ministro extraordinário para o planejamento de coordenação econômica, com o objetivo de proceder ao "exame dos projetos elaborados e o preparo de outros considerados essenciais à obtenção de rendimento e produtividade da administração federal" (Wahrlich, 1974:44).

Do trabalho dessa comissão e das revisões que se seguiram em âmbito ministerial resultou a edição do Decreto-Lei no 200, de 25 de fevereiro de 1967, o mais sistemático e ambicioso empreendimento para a reforma da administração federal. Esse dispositivo legal era uma espécie de lei orgânica da administração pública, fixando princípios, estabelecendo conceitos, balizando estruturas e determinando providências. O Decreto-Lei ํํ 200 se apoiava numa doutrina consistente e definia preceitos claros de organização e funcionamento da máquina administrativa.

Em primeiro lugar, prescrevia que a administração pública deveria se guiar pelos princípios do planejamento, da coordenação, da descentralização, da delegação de competência e do controle. Em segundo, estabelecia a distinção entre a administração direta — os ministérios e demais órgãos diretamente subordinados ao presidente da República - e a indireta, constituída pelos órgãos descentralizados - autarquias, fundações, empresas públicas e sociedades de economia mista. Em terceiro, fixava a estrutura do Poder Executivo federal, indicando os órgãos de assistência imediata do presidente da República e distribuindo os ministérios entre os setores político, econômico, social, militar e de planejamento, além de apontar os órgãos essenciais comuns aos diversos ministérios. Em quarto, desenhava os sistemas de atividades auxiliares-pessoal, orçamento, estatística, administração financeira, contabilidade e auditoria e serviços gerais. Em quinto, definia as bases do controle externo e interno. Em sexto, indicava diretrizes gerais para um novo plano de classificação de cargos. E finalmente, estatuía normas de aquisição e contratação de bens e serviços. 
Para Beatriz Wahrlich (1984:52) de 1964 até 1978 assistiu-se ao ressurgimento da reforma administrativa como programa de governo formal.

De 1967 a 1979, a coordenação da reforma administrativa cabia à Semor (Subsecretaria de Modernização e Reforma Administrativa), que cuidava dos aspectos estruturais, sistêmicos e processuais, e ao Dasp, que atuava somente no domínio dos recursos humanos. Nesta fase, a Semor se preocupou em recorrer a freqüentes exames da estrutura organizacional e analisou projetos de iniciativa de outros departamentos, visando à criação, fusão ou extinção de órgãos e programas que trouxessem maior eficácia à gestão pública. Foram realizados muitos estudos, trazendo contribuições importantes para a formulação do arcabouço teórico e de metodologias que embasassem a modernização administrativa. Quanto às Dasp, além de suas atividades regulares, seu principal projeto foi a elaboração de um novo plano de classificação de cargos, que se pautava numa classificação por categoria, em oposição ao anterior, aprovado em 1960, que se apoiava num sistema de classificação por deveres e responsabilidades. Esse plano não logrou êxito em modificar a estrutura hierárquica de cargos na administração pública, o que significa dizer que o sistema de mérito continuou restrito aos postos iniciais da carreira.

Apesar da distância entre as metas estabelecidas e as metas cumpridas, não resta dúvida de que o Decreto-Lei no 200 contribuiu para a consolidação do modelo de administração para o desenvolvimento no Brasil. Essa nova concepção viria substituir o modelo clássico de burocratização, baseado nas idéias de Taylor, Fayol e Weber. Adaptado à nova condição política do Brasil, que atravessava uma ditadura militar, ambicionava expandir a intervenção do Estado na vida econômica e social. A modificação do estatuto do funcionalismo de estatutário para celetista ${ }^{7}$ e a criação de instituições da administração descentralizada visavam facilitar as pretensões intervencionistas do governo.

A tentativa de modernização do aparelho de Estado, especialmente a partir da década de 1960, teve como conseqüência a multiplicação de entida-

\footnotetext{
${ }^{7}$ As expressões estatutário e celetista referem-se ao regime jurídico das relações de trabalho do Estado com os servidores públicos, que poderiam ser regidos pelo Estatuto dos Funcionários Públicos Civis da União (estatutários) ou pela Consolidação da Legislação do Trabalho - CLT (celetistas), esta última comum a todas as relações de emprego. Com a Constituição de 1988, foi instituído o Regime Jurídico Único (RJU) do servidor público, transformando os empregados celetistas estáveis em funcionários estatutários. A Emenda Constitucional no 19, promulgada em maio de 1998, criou a figura jurídica do emprego público, que ainda não foi regulamentada.
} 
des da administração indireta: fundações, empresas públicas, sociedades de economia mista e autarquias. A expansão e a multiplicação de novos centros de administração indireta buscavam maior agilidade e flexibilidade de atuação dessas entidades, melhor atendimento às demandas do Estado e da sociedade, facilidade de aporte de recursos e, naturalmente, facilidade de recrutamento, seleção e remuneração (Marcelino, 1988:44).

Embora tenha se verificado um crescimento na administração direta, sobretudo com o aumento do número de ministérios que foram desmembrados de outros, a marca maior do modelo do crescimento foi mesmo a expansão da administração indireta. Isso resultou no fenômeno da dicotomia entre o Estado tecnocrático e moderno das instâncias da administração indireta e o Estado burocrático, formal e defasado da administração direta, que subsiste mesmo depois da reforma administrativa de março de 1990 (Marcelino, 1988:44). Esse fenômeno tinha se iniciado ainda no final do primeiro governo Vargas, que entre 1940 e 1945 chegou a criar 21 órgãos descentralizados.

Apesar dos avanços, a reforma de 1967 não logrou eliminar o fosso crescente entre as burocracias públicas instaladas na administração direta e na indireta, nem garantir a profissionalização do serviço público em toda a sua extensão: "Não se institucionalizou uma administração do tipo weberiano; a administração indireta passou a ser utilizada como fonte de recrutamento, prescindindo-se, em geral, do concurso público" (Lima Júnior, 1998:14).

A reforma administrativa embutida no Decreto-Lei no 200 ficou pela metade e fracassou. A crise política do regime militar, que se inicia já em meados dos anos 1970, agrava ainda mais a situação da administração pública, já que a burocracia estatal foi identificada com o sistema autoritário em pleno processo de degeneração (Bresser-Pereira, 1996:273-274).

Antes da descrição da reforma administrativa da Nova República, merecem registro dois programas de reforma elaborados entre 1979 e 1982, a desburocratização e a desestatização. De iniciativa do Poder Executivo, os dois programas foram concebidos de forma a atender objetivos complementares que seriam o aumento da eficiência e eficácia na administração pública e o fortalecimento do sistema de livre empresa. Mais especificamente, o programa de desburocratização, instituído pelo Decreto-Lei no 83.740, de 18 de julho de 1979, "visa à simplificação e à racionalização das normas organizacionais, de modo a tornar os órgãos públicos mais dinâmicos e mais ágeis" (Wahrlich, 1984:53). Esperava-se que a supressão de etapas desnecessárias tornaria mais ágil o sistema administrativo, trazendo benefícios para funcionários e clientes. Diferentemente dos outros programas, o da desburocratização privilegiava o 
usuário do serviço público. Daí o seu ineditismo, porque nenhum outro programa antes era dotado de caráter social e político. Mas, ele também incluía entre seus objetivos o enxugamento da máquina estatal, já que recomendava a eliminação de órgãos pouco úteis ou cuidava para impedir a proliferação de entidades com tarefas pouco definidas ou já desempenhadas em outras instituições da administração direta e indireta.

O balanço de sua atuação registrou até março de 1981 a análise de centenas de rotinas de trabalho, para efeito de simplificação, procedendo à supressão de documentos e informações dispensáveis. Em 1983, ele ganha estatuto de ministério, depois de passar por uma fase que volta a ser um programa, a desburocratização recupera na Nova República sua condição de ministério, quando é suprimida definitivamente em 1986.

O programa de desestatização visava ao fortalecimento do sistema livre de empresa e tinha os seguintes pressupostos:

v organização e exploração das atividades econômicas competem preferencialmente à empresa privada, na forma estabelecida na Constituição brasileira. O papel do Estado, no campo econômico, é de caráter suplementar, e visa sobretudo encorajar e apoiar o setor privado;

$\checkmark$ o governo brasileiro está firmemente empenhado em promover a privatização das empresas estatais nos casos em que o controle público se tenha tornado desnecessário ou injustificável;

v a privatização das empresas estatais, porém, não deverá alcançar nem enfraquecer as entidades que devam ser mantidas sob controle público, seja por motivos de segurança nacional, seja porque tais empresas criem, efetivamente condições favoráveis ao desenvolvimento do próprio setor privado nacional, ou ainda, quando contribuem para assegurar o controle nacional do processo de desenvolvimento (Wahrlich, 1984:54).

Para Beatriz Wahrlich (1984:57), o programa da desestatização havia sido concebido para estabelecer limites aos excessos de expansão da administração pública descentralizada, tendência marcante na década anterior sem, entretanto, se configurar na reversão desse processo. Ela completa:

a necessidade de um programa de desestatização indica que na questão da organização para o desenvolvimento, a administração pública brasileira ultrapassou suas metas e chegou a hora de corrigir a disfunção existente, para atender à opção constitucional do país por uma economia de mercado. 


\section{A reforma administrativa da Nova República}

A reforma do Estado era uma das principais promessas da Nova República, que se traduzia em diversas bandeiras de luta que iam muito além do rearranjo administrativo - vigência efetiva do império da lei, desobstrução do Legislativo, aparelhamento da Justiça, reforma tributária, descentralização e, subsidiariamente, reforma agrária, saneamento da previdência, implantação do sistema único de saúde, erradicação do analfabetismo, reforma do ensino básico, desenvolvimento regional.

Tancredo Neves promoveu uma pequena reforma administrativa destinada a acomodar os interesses das diversas facções políticas que o apoiavam — ampliação do número de ministérios e criação de novas diretorias em quase todas as empresas estatais. A verdadeira reforma do Estado, prometia, viria depois da posse. Para realizar essa imensa tarefa, ele indicou um ministro extraordinário da administração para dirigir o velho e desgastado Dasp.

O governo civil que acabara de se instalar em 1985, após mais de duas décadas de ditadura militar, herdava um aparato administrativo marcado ainda pela excessiva centralização. Apesar de representar a primeira tentativa de reforma gerencial da administração pública pela intenção de mexer na rigidez burocrática, o Decreto-Lei no 200/67 deixou seqüelas negativas. Em primeiro lugar, o ingresso de funcionários sem concurso público permitiu a reprodução de velhas práticas patrimonialistas e fisiológicas. E, por último, a negligência com a administração direta — burocrática e rígida — que não sofreu mudanças significativas na vigência do decreto, enfraquece o núcleo estratégico do Estado, fato agravado pelo senso oportunista do regime militar que deixa de investir na formação de quadros especializados para os altos escalões do serviço público.

No final das mais de duas décadas de regime ditatorial a situação do país não era muito alentadora. Paralelamente ao desafio da redemocratização, lidava-se com uma severa crise econômica marcada pelas crescentes desigualdades sociais. As distorções no aparelho administrativo, geradas até o momento, dificultavam qualquer tentativa de reversão desse quadro. Ora, se para realizar mudanças importantes na engrenagem administrativa era necessário uma revisão crítica de todas as experiências anteriores, a missão mais urgente que se apresentava nos meados dos anos 1980 era a instalação de sistemas administrativos capazes de promover o desenvolvimento, fazendo com que o país pudesse dispor de toda a potencialidade de seus recursos. É importante sublinhar, portanto, que o processo de reforma está estreitamente ligado ao contexto político, social e cultural do país, o que significa que não se pode enfatizar somente os aspectos legal e técnico. 
Assim, o governo da chamada Nova República teria como tarefa inadiável a reversão desse quadro, que se expressaria na necessidade de tornar o aparelho administrativo mais reduzido, orgânico, eficiente e receptivo às demandas da sociedade (Marcelino, 2003:645).

Para empreender tamanha tarefa, o governo Sarney instituiu uma numerosa comissão, cujos objetivos eram extremamente ambiciosos, já que, num primeiro momento, pretendia redefinir o papel do Estado (nas três esferas de governo); estabelecer as bases do funcionamento da administração pública; fixar o destino da função pública; reformular as estruturas do Poder Executivo federal e de seus órgãos e entidades; racionalizar os procedimentos administrativos em vigor; além de traçar metas para áreas consideradas prioritárias, como a organização federal, recursos humanos e a informatização do setor público. Nessa época, ainda operavam os programas de privatização e desburocratização herdados do governo Figueiredo.

Segundo Marcelino (2003:646), o documento elaborado pela comissão geral da reforma define as propostas para a reorganização da administração pública:

$\checkmark$ restauração da cidadania para prover os cidadãos de meios para a realização de seus direitos, obedecendo aos critérios de universalidade e acesso irrestrito;

$\checkmark$ democratização da ação administrativa em todos os níveis do governo, por meio de dinamização, redução do formalismo e transparência dos mecanismos de controle, controle do Poder Executivo pelo Poder Legislativo e pela sociedade, e articulação e proposição de novas modalidades organizacionais de decisão, execução e controle administrativo-institucional;

v descentralização e desconcentração da ação administrativa com o objetivo de situar a decisão pública próxima do local de ação, além de reverter o processo de crescimento desordenado da administração federal;

จ revitalização do serviço público e valorização dos serviços;

v melhoria dos padrões de desempenho a fim de promover a alocação mais eficiente de recursos.

Essa comissão, criada em agosto de 1985, suspende seus trabalhos em fevereiro de 1986, quando todas as atenções e esforços estavam voltados para o plano de estabilização da economia - o Plano Cruzado. Em setembro daquele mesmo ano, é lançado o primeiro programa de reformas do governo Sarney, que tinha três objetivos principais: racionalização das estruturas admi- 
nistrativas, formulação de uma política de recursos humanos e contenção de gastos públicos (Marcelino, 2003:647).

Quanto à estrutura, o que se pretendia era fortalecer a administração direta com base na assertiva de que ela tinha sido negligenciada em detrimento da administração indireta, que acusava altos níveis de expansão ano após ano, desde o começo das reformas. Para estancar o crescimento dos órgãos da administração indireta e promover o desenvolvimento da direta, elaborou-se uma primeira versão da Lei Orgânica da Administração Pública Federal, que sucedia o Decreto-Lei no 200.

Valorizar a função pública e promover a renovação de quadros eram as metas principais da política de recursos humanos do governo Sarney. Para isso, foram criadas a Escola Nacional de Administração Pública (Enap) e o Centro de Desenvolvimento da Administração Pública (Cedam), ambos vinculados à Secretaria de Recursos Humanos. O primeiro seria responsável pela formação de novos dirigentes do setor público e ao segundo caberia a função de treinar e reciclar servidores públicos, objetivando uma alocação mais lógica e racional de funcionários públicos. Complementando essa política, a Secretaria de Administração Pública (Sedap), ao tentar resgatar o sistema de mérito, elaborou um novo plano de carreira, uma revisão do estatuto do funcionalismo e um plano de retribuições.

Na prática, nem a comissão, nem o grupo executivo que a sucedeu conseguiu implementar as medidas que preconizaram. A ampla reforma modernizadora e democrática foi deixada de lado para dar lugar à mais tradicional estratégia de reforma administrativa - a racionalização dos meios. Mas mesmo com a emulação suscitada pelo Plano Cruzado, o governo não foi capaz de reativar as antigas ilhas de eficiência do setor público - planejamento, arrecadação, comunicações, política agrícola - desmanteladas a partir do início da gestão de Delfim Neto na Secretaria de Planejamento, da presidência da República, no governo Figueiredo. Por outro lado, como medidas de racionalização, o governo Sarney extinguiu o Banco Nacional de Habitação (BNH), que enfrentava grave crise na lógica de financiamento da casa própria e, com ele, a política de habitação, cuja responsabilidade, em parte, foi transferida para a Caixa Econômica Federal (CEF). Também pouco avançou na implementação do Sistema Único de Saúde (SUS), duramente conquistado na Constituinte.

No campo da política de recursos humanos do setor público, o governo não conseguiu instituir um sistema de carreiras, apoiando o progresso profissional na formação dos servidores, que justificasse a existência desses organismos. Deixou para seu sucessor o projeto de um regime único para os servidores públicos, determinado pela Constituição de 1988 que, cedendo 
a pressões de interesses corporativos, estabelecia mais de 100 direitos, uns dois ou três deveres e alguns poucos dispositivos sobre o processo disciplinar e as sanções cabíveis em caso de falta grave (Lei no 8.112, de 11 de dezembro de 1990, mais tarde, profundamente alterada pela Lei oㅜ 9.527, de 10 de dezembro de 1997). Sancionado com vetos posteriormente derrubados pelo Congresso Nacional, esse emblema do privilégio em nada contribuiu para valorizar a função pública.

Para Gileno Marcelino (1988), as tentativas de reforma até 1985 careceram de planejamento governamental e de meios mais eficazes de implementação. Havia uma relativa distância entre planejamento, modernização e recursos humanos, além da falta de integração entre os órgãos responsáveis pela coordenação das reformas. Os resultados dessa experiência foram relativamente nefastos e se traduziram na multiplicação de entidades, na marginalização do funcionalismo, na descontinuidade administrativa e no enfraquecimento do Dasp. Em resumo, a experiência das reformas administrativas no Brasil apresentou distorções na coordenação e avaliação do processo, o que dificultou a sua implementação nos moldes idealizados. Persistia na sua concepção uma enorme distância entre as funções de planejamento, modernização e recursos humanos.

Paralelamente às tentativas de reforma empreendidas pelo governo, tinham início os trabalhos da Assembléia Nacional Constituinte, eleita em 1986 e instalada no começo de 1987. A Constituinte pretendia, com a nova Carta, refundar a República, estabelecendo outras bases para a soberania, a ordem social, a cidadania, a organização do Estado, as formas de deliberação coletiva, o financiamento do gasto público, as políticas públicas e a administração pública. A Constituição de 1988 proclamou uma nova enunciação dos direitos de cidadania, ampliou os mecanismos de inclusão política e participação, estabeleceu larga faixa de intervenção do Estado no domínio econômico, redistribuiu os ingressos públicos entre as esferas de governo, diminuiu o aparato repressivo herdado do regime militar e institucionalizou os instrumentos de política social, dando-lhes substância de direção. Nesse sentido, a promulgação da Carta Magna representou uma verdadeira reforma do Estado.

Entretanto, do ponto de vista da gestão pública, a Carta de 1988, no anseio de reduzir as disparidades entre a administração central e a descentralizada, acabou por eliminar a flexibilidade com que contava a administração indireta que, apesar de casos de ineficiência e abusos localizados em termos de remuneração, constituía o setor dinâmico da administração pública. Ela foi equiparada, para efeito de mecanismos de controle e procedimentos, à 
administração direta. ${ }^{8}$ A aplicação de um regime jurídico único (RJU) a todos os servidores públicos abruptamente transformou milhares de empregados celetistas em estatutários, ${ }^{9}$ gerando um problema ainda não solucionado para a gestão da previdência dos servidores públicos, pois assegurou aposentadorias com salário integral para todos aqueles que foram incorporados compulsoriamente ao novo regime sem que nunca tivessem contribuído para esse sistema. Além disso, o RJU institucionalizou vantagens e benefícios que permitiram um crescimento vegetativo e fora de controle das despesas com pessoal, criando sérios obstáculos ao equilíbrio das contas públicas e aos esforços de modernização administrativa em todos os níveis de governo.

Apesar do propalado retrocesso em termos gerenciais, a Constituição de 1988 não deixou de produzir avanços significativos, particularmente no que se refere à democratização da esfera pública. Atendendo aos clamores de participação nas decisões públicas, foram institucionalizados mecanismos de democracia direta, favorecendo um maior controle social da gestão estatal, incentivou-se a descentralização político-administrativa e resgatou-se a importância da função de planejamento.

Embora tenha participado da administração do presidente Sarney, Bresser-Pereira (1998:274) faz uma crítica mais contundente às tentativas de reforma do governo da transição democrática e às mudanças introduzidas pela Constituição de 1988. Ele acredita que, no plano gerencial, houve uma volta aos ideais burocráticos dos anos 1930 e, no plano político, uma tentativa de retorno ao populismo dos anos 1950. Partindo de uma perspectiva de análise política, considera que os dois partidos que comandaram a transição eram, apesar de democráticos, visceralmente populistas, não tinham, como a sociedade brasileira também não tinha, noção da gravidade da crise que o país estava atravessando. Havia, ainda, uma espécie de euforia democrático-populista. Uma idéia de que seria possível voltar aos anos dourados da democracia e do desenvolvimento brasileiro, que foram os anos 1950.

\footnotetext{
${ }^{8}$ O Decreto-Lei no 200, de 25 de fevereiro de 1967, estabeleceu a distinção entre administração direta (ou centralizada) e administração indireta (ou descentralizada), englobando na primeira apenas os ministérios e seus órgãos constitutivos, inclusive os relativamente autônomos e, na indireta, as autarquias, fundações, empresas públicas e sociedades de economia mista.

${ }^{9}$ Relação de emprego regida pela Consolidação das Leis do Trabalho (CLT), que vale tanto para os empregados das empresas privadas quanto para os das estatais. Até 1988, esse regime também era utilizado na contratação de servidores de autarquias, fundações e mesmo de alguns órgãos da administração direta. Eram chamados de estatutários os funcionários regidos pelo antigo Estatuto dos Servidores Civis da União. Na prática, o RJU transformou todos os empregados públicos em funcionários estatutários.
} 


\section{A reforma do governo Collor}

Em 15 de março de 1990, tomou posse o primeiro governo civil eleito pelo voto direto, nos últimos 30 anos, de um século de vida republicana. Para cumprir seus propósitos reformadores criou uma nova moeda, congelou a poupança popular, taxou haveres financeiros e redesenhou a máquina de governo. Em menos de 24 horas, editou 23 medidas provisórias, sete decretos e 72 atos de nomeação, aos quais se seguiram inúmeras portarias ministeriais e instruções normativas autárquicas. Com o objetivo de reduzir a intervenção do Estado na vida social, criou uma série de restrições e regulamentos temporários para que, aos poucos, os cidadãos perdessem a memória inflacionária e pudessem usufruir mais os benefícios decorrentes do exercício das novas liberdades.

Na perspectiva econômica, o Plano Collor fomentou debates, ensaios e livros. Sob as lentes do direito, as medidas legais dele decorrentes têm gerado pareceres, polêmicas e milhares de demandas judiciais. Esses dois pontos de vista monopolizaram o interesse e a atenção dos meios de comunicação e, em conseqüência, da sociedade como um todo. Hoje, são de conhecimento perfeitamente acessível o impacto do inciso de um artigo de uma lei de conversão, a alíquota de IOF que incide sobre cada ativo financeiro e as projeções sobre os estoques de base monetária e da moeda em circulação.

É verdade que a extinção de alguns órgãos que cumpriam missões mais relevantes e as demissões em todas as áreas provocaram vivas discussões. Questionou-se, por exemplo, o propósito do desmantelamento do aparelho de promoção cultural e o fundamento ético das demissões em massa numa conjuntura econômica recessiva. Afora o questionamento sobre sua eficácia em termos de efetiva redução de custos, os argumentos que se alinhavam a favor e contra sua adoção fundamentam-se em paradigmas de rationale não semelhantes, a começar por duas ou três concepções de Estado que supõem diferentes níveis de aparelhamento e limites de intervenção. Perdeu-se, nessa perspectiva, até o que havia de consensual antes da posse do presidente Collor - a necessidade de redefinir o papel do Estado e redimensionar o tamanho do governo.

É claro que não houve um balizamento conceitual, um conteúdo estratégico bem definido e um planejamento da implementação suficientemente estruturado mas, ainda assim, constituiu-se um amplo processo de reforma administrativa do Poder Executivo, embora com uma inversão de fatores, ou seja, existia uma função à procura de um enredo.

Evidentemente, existem outros modelos de reforma ou modernização administrativa cujo foco de intervenção pode ser orientado para diferentes di- 
mensões do fenômeno macro-organizacional. ${ }^{10}$ Mas a redistribuição de autoridade e responsabilidade por diferentes áreas de especialização, organismos e níveis hierárquicos pode caracterizar, por si só, a mudança organizacional e constituir o conteúdo da reforma administrativa.

A rápida passagem de Collor pela presidência provocou, na administração pública, uma desagregação e um estrago cultural e psicológico impressionantes. A administração pública sentiu profundamente os golpes desferidos pelo governo Collor, com os servidores descendo aos degraus mais baixos da auto-estima e valorização social, depois de serem alvos preferenciais em uma campanha política altamente destrutiva e desagregadora.

Torres (2004:170)

Sua reforma administrativa caminhou de forma errática e irresponsável no sentido da desestatização e da racionalização. ${ }^{11}$ As medidas de racionalização foram conduzidas de maneira perversa e equivocada. Algumas das extinções tiveram que ser logo revistas, como a da Capes, por exemplo. Muitas das fusões, principalmente de ministérios, não eram convenientes, pois criavam superestruturas (como os ministérios da Economia e da Infra-Estrutura) sujeitas a pressões de interesses poderosos, e dificultavam a supervisão que intentavam favorecer. Os cortes de pessoal, desnecessários, se examinarmos a administração como um todo, não trouxeram expressiva redução de custos. A reforma administrativa desmantelou os aparelhos de promoção da cultura e contribuiu ou, pelo menos, serviu de pretexto para a paralisação de todos os programas sociais. Depois do início da crise de seu governo, Collor voltou ao velho sistema de concessões políticas para atrair apoios, desmembrando e criando ministérios.

O governo Collor também prometeu uma reforma do Estado orientada numa outra direção. Se ela fosse sincera nos seus propósitos poderia, como já

\footnotetext{
${ }^{10}$ Os principais modelos de análise e intervenção organizacional utilizados no processo de reforma administrativa e a proposta "de mudança ambiental planejada" são expostos em Motta, 1979:153.

${ }^{11}$ Essas categorias foram desenvolvidas para melhor compreender a reforma administrativa do governo Collor. A desestatização parte da premissa que não cabe ao Estado realizar determinadas funções, e a racionalização se apóia no critério da eficiência e parte do pressuposto que, entre as funções indelegáveis, o Estado pode, com menos recursos, realizar o mesmo volume de atividades ou, em outros casos, com o mesmo volume de recursos, realizar um maior número de atividades (Lustosa da Costa e Cavalcanti, 1991:82).
} 
vimos, contribuir para a consolidação e universalização do Estado mínimo, e assim assegurar o bem-estar dos cidadãos brasileiros. Na verdade, movida a oportunismo neoliberal e constituída como uma empresa de desmantelamento do setor público, ela produziu uma série de remanejamentos no plano da organização administrativa, desarticulou as estruturas encarregadas de operar políticas compensatórias e em nada contribuiu para a garantia de direitos civis ou de direitos sociais básicos. ${ }^{12}$

O governo Itamar Franco, dado o seu caráter de excepcionalidade, adotou uma postura tímida e conservadora com relação à reforma do Estado e mesmo à reforma administrativa. Para conservar a ampla base de apoio que possibilitou a sua emergência, persistiu na estratégia de ressucitar ministérios extintos por Collor e restringiu-se a tocar, de forma hesitante, o programa de privatização.

Esse relato inicial não contempla o período dos mandatos do presidente Fernando Henrique Cardoso, que é objeto de análise detalhada mais à frente.

\section{A reforma Bresser}

No Brasil dos anos 1990, o debate sobre a reforma do Estado foi liderado pelo professor Luis Carlos Bresser-Pereira, seja na qualidade de scholar, seja na qualidade de ministro. Manifestando-se num ou noutro papel, seus argumentos e propostas foram sempre basicamente os mesmos e estão resumidos no Plano Diretor da Reforma do Aparelho de Estado - Pdrae (1995). O documento está dividido em nove partes e apresenta, entre outros, os seguintes pontos:

v uma breve interpretação da crise do Estado;

v uma classificação evolutiva da administração pública;

v um histórico das reformas administrativas no Brasil a partir dos anos 1930;

$\checkmark$ um diagnóstico da administração pública brasileira;

$\checkmark$ um quadro referencial das formas de propriedade, setores do Estado e tipos de gestão;

\footnotetext{
${ }^{12}$ Uma avaliação da concepção de Estado, das dimensões técnicas e do impacto inicial da reforma administrativa empreendida no governo Collor está em Costa e Cavalcanti, 1991.
} 
$\checkmark$ uma estratégia de mudança;

$\checkmark$ os principais projetos de reforma do chamado aparelho de Estado.

O Plano Diretor da Reforma do Aparelho de Estado tinha como proposta explícita inaugurar a chamada "administração gerencial", o que parece designar, como veremos, o fim da história da administração pública, espécie de panacéia redentora do estatismo patrimonialista e do ogro burocrático.

O Pdrae partia de uma premissa - a de que a crise latino-americana era uma crise do Estado. Com base nesse diagnóstico, o plano indicou como pilares do projeto de reforma do Estado:

$\checkmark$ ajustamento fiscal duradouro;

- reformas econômicas orientadas para o mercado que, acompanhadas de uma política industrial e tecnológica, garantissem a concorrência interna e criassem condições para o enfrentamento da competição internacional;

v a reforma da previdência social;

v a inovação dos instrumentos de política social, proporcionando maior abrangência e promovendo melhor qualidade para os serviços sociais;

v a reforma do aparelho de Estado, com vistas a aumentar sua "governança", ou seja, sua capacidade de implementar de forma eficiente políticas públicas.

Segundo o Pdrae, o governo brasileiro, no âmbito dos três poderes, "não carecia de 'governabilidade', ou seja, de poder para governar, dada sua legitimidade democrática e o apoio com que contava na sociedade civil. Enfrentava, entretanto, um problema de governança, na medida em que sua capacidade de implementar as política públicas estava limitada pela rigidez e ineficiência da máquina administrativa" (Mare, p. 3-4).

A reforma do Estado deve ser entendida dentro do contexto da redefinição do papel do Estado, que deixa de ser o responsável direto pelo desenvolvimento econômico e social, para se tornar seu promotor e regulador. O Estado assume um papel menos executor ou prestador direto de serviços mantendo-se, entretanto, no papel de regulador e provedor destes. Nesta nova perspectiva, busca-se o fortalecimento das suas funções de regulação e de coordenação, particularmente no nível federal, e a progressiva descentralização vertical, para os níveis estadual e municipal, das funções executivas no campo da prestação de serviços sociais e de infra-estrutura. Considerando essa tendência, pretende-se reforçar a governança - a capacidade de governo do 
Estado - por meio da transição programada de um tipo de administração pública burocrática, rígida e ineficiente, voltada para si própria e para o controle interno, para uma administração pública gerencial, flexível e eficiente, voltada para o atendimento da cidadania. Para isso, será necessária uma mudança em três planos: no plano institucional-legal, através da reforma da Constituição e das leis do país; no plano cultural, através da internalização de uma nova visão do que seja a administração pública; e no plano da gestão, onde afinal se concretiza a reforma (Mare, p. 4).

Para realizar tarefa de tal envergadura, o Pdrae assinalava ser necessário:

v a redefinição dos objetivos da administração pública, voltando-a para o cidadão-cliente;

v o aperfeiçoamento dos instrumentos de coordenação, formulação e implementação e avaliação de política públicas;

v a flexibilização de normas e a simplificação de procedimentos;

$\checkmark$ o redesenho de estruturas mais descentralizadas;

- o aprofundamento das idéias de profissionalização e de permanente capacitação dos servidores públicos, idéias que vêm da administração pública burocrática, mas que jamais foram nela plenamente desenvolvidas.

\section{O modelo conceitual}

O modelo conceitual da Reforma do Aparelho de Estado está apoiado em três dimensões: formas de propriedade, tipos de administração pública e níveis de atuação do Estado. As relações entre essas dimensões estabelecem o quadro referencial e a estratégia da reforma.

Tradicionalmente, o senso comum e a ciência do direito distinguem dois tipos de propriedade - a pública e a privada, sendo pública toda aquela que está no domínio do Estado, e privada, por exclusão, todas as demais, que ordinariamente se diz estarem na esfera do mercado. O modelo propõe que a propriedade pública possa ser classificada em dois tipos: a propriedade pública estatal e a propriedade pública não-estatal. A propriedade estatal seria aquela tradicionalmente designada como propriedade pública, ou seja, o conjunto de bens sob controle estatal. Já a propriedade pública não-estatal compreenderia todos aqueles bens que, embora não sejam propriedade do Estado, servem ao interesse público. Está nessa categoria o patrimônio de todas as instituições sem fins lucrativos dedicadas a prestar serviços à comunidade, como as 
fundações, as associações sem fins lucrativos, as sociedades civis de interesse público, as beneficências. Na hipótese de extinção, o patrimônio delas reverte ao Estado.

Bresser-Pereira chama a atenção para o fato de que a existência desse tipo de propriedade gera direitos de cidadania, os chamados direitos republicanos, que não têm titular certo, mas afetam o bem-estar e a sobrevivência de todos os indivíduos em novas formas de apropriação do mundo e de inserção na vida social. Eles dão ao cidadão direitos ao futuro comum, à informação fidedigna, à proteção ao meio ambiente, ao patrimônio histórico e à coisa pública. Bresser-Pereir (1997:121) não inclui a proteção do consumidor entre os direitos republicanos. Apoiado na obra de Luís Felipe Colaço Antunes (1989), ele argumenta que

este é um direito que pode ser coletivo, à medida que seu titular freqüentemente é um grupo, categoria ou classe de pessoas ligadas entre si. (...) É um direito civil, é um direito subordinado ao direito de propriedade. O direito do consumidor, embora possa ser visto como coletivo, é no fundo um direito privado: expressa o direito do comprador de bens de consumo de não ser enganado.

O mesmo raciocínio sobre o caráter individual de um direito coletivo pode ser aplicado ao direito à privacidade e à proteção contra a onisciência dos computadores.

O modelo também distingue três tipos de administração pública: a patrimonialista, a burocrática e a gerencial. Na administração pública patrimonialista,

o aparelho do Estado funciona como uma extensão do poder do soberano, e os seus auxiliares, servidores, possuem status de nobreza real. Os cargos são considerados prebendas. A res publica não é diferenciada da res principis. Em conseqüência, a corrupção e o nepotismo são inerentes a esse tipo de administração. No momento em que o capitalismo e a democracia se tornam dominantes, o mercado e a sociedade civil passam a se distinguir do Estado. Neste novo momento histórico, a administração patrimonialista torna-se uma excrescência inaceitável.

(Mare, p. 15).

A administração pública burocrática se caracteriza pela profissionalização, a idéia de carreira, a hierarquia funcional, a impessoalidade, o formalis- 
mo, em síntese, o poder racional legal. Os controles administrativos, visando evitar a corrupção e o nepotismo, são sempre a priori. Parte-se de uma desconfiança prévia nos administradores públicos e nos cidadãos que a eles dirigem demandas (Mare, p. 15). O controle rígido dos processos volta-se para a administração de pessoal, as compras e o processamento de demandas. A administração pública gerencial é "orientada predominantemente pelos valores da eficiência e da qualidade na prestação de serviços públicos e pelo desenvolvimento de uma cultura gerencial nas organizações". Não nega todos os princípios da administração pública burocrática, pois tem uma clara noção do interesse público e conserva, embora flexibilizando-os, "a admissão segundo rígidos critérios de mérito, a existência de um sistema estruturado e universal de remuneração, as carreiras, a avaliação constante de desempenho, o treinamento sistemático". A principal diferença está na forma de controle "que deixa de se basear nos processos para se concentrar nos resultados" (Mare, p. 16). A administração pública gerencial volta-se para:

v a definição precisa dos objetivos que o administrador público deverá atingir em sua unidade;

v a garantia de autonomia do administrador na gestão dos recursos humanos, materiais e financeiros que lhe foram colocados à disposição;

v o controle ou cobrança a posteriori dos resultados.

Adicionalmente, praticar-se-ia a competição administrada no interior do próprio Estado, quando houvesse a possibilidade de estabelecer concorrência entre unidades internas. No plano da estrutura organizacional, a descentralização e a redução dos níveis hierárquicos tornar-se-iam centrais.

Em suma, afirmava-se que a administração pública deve ser permeável à maior participação dos agentes privados e das organizações da sociedade civil, deslocando-se a ênfase dos procedimentos (meios) para os resultados (fins):

o paradigma gerencial contemporâneo, fundamentado nos princípios de confiança e de descentralização da decisão, exige formas flexíveis de gestão, horizontalização de estruturas, descentralização de funções, incentivo à criatividade. Contrapõe-se à ideologia do formalismo e do rigor técnico da burocracia tradicional. À avaliação sistemática, à recompensa pelo desempenho, e à capacitação permanente, que já eram características da boa administração burocrática, acrescentam-se os princípios da orientação para o cidadão cliente, do controle por resultados, e da competição administrada.

(Mare, p. 17). 
Essas categorias deixam entrever o caráter evolutivo e voluntarista da proposta. Sugere-se que tivemos uma administração patrimonialista, que evoluiu para o modelo burocrático e estamos caminhando para a administração gerencial, uma espécie de fim da história da administração pública. A própria designação administração é infeliz pleonasmo nascido de uma tradução inadequada da new public management. Falar em dotar a administração pública de uma cultura gerencial não quer dizer nada. Todas as organizações possuem cultura gerencial — algumas mais burocráticas; outras mais orgânicas e flexíveis.

De acordo com o plano, também há que se distinguir ainda três níveis de atuação do Estado:

- central ou estratégico, incumbido de formular, supervisionar e avaliar a implementação das políticas públicas compostas pelo governo, a cúpula dos três poderes da República e o Ministério Público;

v descentralizado, responsável pela execução das políticas e atividades exclusivas, como regulação, fiscalização, segurança, previdência básica;

v de funções não-exclusivas do Estado, no qual bens e serviços públicos em hospitais, escolas, centros culturais e centros de pesquisa podem ser fornecidos por organizações estatais ou da sociedade civil — associações sem fins lucrativos e mesmo empresas privadas - sujeitas ao controle social.

A produção de bens e serviços para o mercado ficaria a cargo das empresas privadas. A cada um desses níveis funcionais corresponderia um tipo específico de agência pública.

Esse esquema engenhoso resume toda a base conceitual da reforma gerencial brasileira, estabelecendo numa matriz diferentes formas de propriedade, tipos de administração pública e níveis de atividade, para definir os projetos de intervenção. Ele mostra que a administração gerencial é o tipo mais adequado à gestão de agências autônomas, organizações públicas não-estatais (não-governamentais) e empresas privadas, mas que há ainda um espaço residual para a administração burocrática. Chama a atenção a existência de uma relação entre o tipo de propriedade (ou espaço institucional - Estado, mercado e sociedade) e o tipo de atividade. Tal correspondência pode ser encontrada em dois quadros apresentados por Osborne e Gaebler (1997) para indicar tipos de atividade onde são mais efetivas instituições públicas, organizações governamentais e empresas privadas. 


\section{Os instrumentos de intervenção}

A reforma, tal como preconizada no Plano Diretor, pode ser interpretada com cinco diretrizes principais, a saber:

v institucionalização, considera que a reforma só pode ser concretizada com a alteração da base legal, a partir da reforma da própria Constituição;

$\checkmark$ racionalização, que busca aumentar a eficiência, por meio de cortes de gastos, sem perda de "produção", fazendo a mesma quantidade de bens ou serviços (ou até mesmo mais) com o mesmo volume de recursos;

v flexibilização, que pretende oferecer maior autonomia aos gestores públicos na administração dos recursos humanos, materiais e financeiros colocados à sua disposição, estabelecendo o controle e cobrança a posteriori dos resultados;

v publicização, que constitui uma variedade de flexibilização baseada na transferência para organizações públicas não-estatais de atividades não exclusivas do Estado (devolution), sobretudo nas áreas de saúde, educação, cultura, ciência e tecnologia e meio ambiente;

v desestatização, que compreende a privatização, a terceirização e a desregulamentação.

Do ponto de vista do Plano Diretor, essas grandes diretrizes se traduziam na mudança institucional introduzida pela Emenda Constitucional no 19 e em três projetos básicos: avaliação estrutural (racionalização), agências executivas (flexibilização) e organizações sociais (publicização). A emenda foi promulgada em junho de 1998, a avaliação estrutural nunca foi realizada pelo governo Fernando Henrique, o projeto de agências executivas resultou na qualificação de um único organismo (Inmetro) e a proposta de publicização resultou no estímulo à criação de apenas cinco organizações sociais. Embora não fizesse parte dos objetivos do Plano Diretor, nem constituísse atribuição do Mare (Ministério da Administração e Reforma do Estado), o maior número de realizações esteve relacionado com a privatização de empresas estatais, principalmente nos setores de telefonia (Sistema Telebrás), mineração (Vale do Rio Doce) e financeiro (Banespa).

\section{Considerações finais - síntese histórica}

Este artigo revela que a organização da administração pública no Brasil passou por transformações importantes desde o período colonial. Parece simplificador 
reduzir a história administrativa do país a dois grandes momentos - antes e depois. Na verdade, a administração colonial conheceu diferentes fases e teve um impulso modernizador com o consulado pombalino. O Império também tem sua organização governamental marcada por etapas bem distintas, destacando-se a adoção do regime parlamentarista e o fortalecimento progressivo dos governos provinciais. A própria República Velha também se caracterizou por avanços e recuos na questão da descentralização e viu nascerem algumas empresas e autarquias e surgirem diferenciações na estrutura ministerial.

É verdade que o primeiro governo Vargas representa um marco, não só porque produziu grandes transformações nas estruturas econômicas, sociais e políticas do país, mas também porque realizou o primeiro esforço deliberado, sistemático e continuado de modernização administrativa. O outro marco é de fato a reforma administrativa de 1967, que padronizou estruturas e procedimentos e introduziu os modernos instrumentos de intervenção.

O terceiro marco na história administrativa mais recente é a reforma dos anos 1990. Ela é precedida de uma crise que desmantelou e sucateou a máquina administrativa brasileira, criando ensejo para a crítica neoliberal. $\mathrm{O}$ que se pode concluir desta análise é que, não obstante os equívocos políticos, conceituais e operacionais e a desastrada estratégia que adotou, a reforma gerencial começou no governo Collor, quando se tentou introduzir, ainda que de forma intuitiva e vacilante, os princípios da new public management.

Este balanço também mostra que não se pode avaliar a experiência de reforma em termos de sucesso ou insucesso absolutos. A não ser aquelas tentativas que não chegaram a produzir efeitos legais e administrativos, todas as reformas introduziram instrumentos que vieram se agregar às práticas vigentes. Nesse sentido, à medida que o país se transformava econômica, social e politicamente, a administração pública se ampliava, se diferenciava e se aparelhava, sempre aumentando a oferta de bens e serviços.

Assim, não obstante os avanços persistentes e os eventuais recuos, a administração pública se modernizou, ganhando em eficiência, especialização técnica, moralidade, publicidade e transparência. Entretanto, esse processo de transformação sempre deixou em segundo plano a questão democrática e a teleologia das reformas e da própria máquina pública.

\section{Referências bibliográficas}

ALBUQUERQUE, Roberto Cavalcanti de. Reconstrução e reforma do Estado. In: VELLOSO, João Paulo dos Reis; ALBUQUERQUE, Roberto Cavalcanti de. (Orgs.). Governabilidade e reformas. Rio de Janeiro: José Olympio, 1995. 
ANTUNES, Luís Felipe Colaço. A tutela dos interesses difusos em direito administrativo: para uma legitimação procedimental. Coimbra: Almedina, 1989.

BERTERO, Carlos Osmar. Perspectivas históricas e eventos recentes. Brasília: Funcep, 1986.

BRESSER-PEREIRA, Luís Carlos. Estado e subdesenvolvimento industrializado. São Paulo: Braziliense, 1977.

. Crise econômica e reforma do Estado no Brasil. Brasília: Ed. 34, 1996.

- Reforma do Estado para a cidadania: a reforma gerencial brasileira na perspectiva internacional. Brasília: Ed. 34, 1998.

. Do Estado patrimonial ao gerencial. In: PINHEIRO, Paulo Sérgio; WILHEIM, Jorge; SACHS, Ignacy (Orgs.). Brasil: um século de transformações. São Paulo: Companhia das Letras, 2001.

; SPINK, Peter (Orgs.). Reforma do Estado e administração pública gerencial. Rio de Janeiro: FGV, 1998.

CALÓGERAS, J. Pandiá. Formação histórica do Brasil. São Paulo: Companhia Editora Nacional, 1980.

CARDOSO, Fernando Henrique. A arte da política: a história que eu vivi. Rio de Janeiro: Civilização Brasileira, 2006.

CARVALHO, Ângela Maria Carneiro de. Principais transformações por que tem passado a organização governamental brasileira, a partir da década de 30 , em conseqüência do modelo de desenvolvimento e das políticas públicas adotadas pelo país. Cadernos Epab, n. 56, 1990.

CARVALHO, José Murilo de. Desenvolvimiento de la ciudadanía en Brasil. México: Fondo de Cultura Económica, 1995. n. 18. 1996.

. Cidadania: tipos e percursos. Estudos Históricos, Rio de Janeiro: FGV,

et al. Lei, justiça e cidadania: cor, religião, acesso a informações e serviços. Rio de Janeiro: Cpdoc, 1998.

. Mandonismo, coronelismo, clientelismo: uma discussão conceitual. Dados, v. 40, n. 2, 1997. Disponível em: <www.scielo.br/scielo.php?script=sci_ arttext\&pid $=$ S0011-52581997000200003\&lng $=$ en\&nrm $=$ iso $>$.

. Visconde de Uruguai. São Paulo: Ed. 34, 2002.

CASTOR, Belmiro Valverde Jobim. O Brasil não é para amadores. Estado, governo e burocracia na terra do jeitinho. Curitiba: Ebel, 2000. 
; FRANÇA, Célio. Administração pública no Brasil: exaustão e revigoramento do modelo. Revista de Administração Pública, v. 20, n. 3, p. 3-26, 1986.

COSTA, Frederico Lustosa da. Estado, reforma do Estado e democracia no Brasil da Nova República. Revista de Administração Pública, v. 32, n. 4, p. 71-82, 1998a.

. A reforma do Estado e as organizações sociais - programa de estudos e pesquisas em reforma do Estado e governança. Revista de Administração Pública, v. 32, n. 5, p. 209-213, 1998b.

. Avaliação preliminar da Reforma do Aparelho de Estado do Maranhão - Programa de Estudos e Pesquisas em Reforma do Estado e Governança. Revista de Administração Pública, Rio de Janeiro, v. 33, n. 1, p. 157-163, jan./fev. 1999a.

. Reforma do Estado: restrições e escapismos no funcionamento das agências autônomas - Programa de Estudos e Pesquisas em Reforma do Estado e Governança. Revista de Administração Pública, v. 33, n. 2, p. 191-199, 1999 b.

; CAVALCANTI, Bianor Scelza. Mudança organizacional no setor público. Revista de Administração Pública, v. 25, n. 1, p. 82-106, 1991.

; PECI, Alketa. Desestatização como estratégia de reforma do Estado: análise preliminar da privatização no Brasil de Nova República. Revista de Administração Pública, v. 33, n. 3, p. 191-207, 1999.

FLEURY, Sonia. Reforma del Estado. Revista de Administração Pública, v. 35, n. 5, p. 7-48, 2001.

. Democracia, descentralização e desenvolvimento. In: Democracia, descentralização e desenvolvimento: Brasil e Espanha. Rio de Janeiro: FGV, 2006.

GRAHAM, Richard. Clientelismo e política no Brasil do século XIX. Rio de Janeiro: UFRJ, 1997.

HOLANDA, Nilson. A crise gerencial do Estado brasileiro. In: VELLOSO, João Paulo dos Reis (Org.). Brasil: a superação da crise. São Paulo: Nobel, 1993.

HOLANDA, Sérgio Buarque de. Raízes do Brasil. São Paulo: Companhia das Letras, 2001.

LACOMBE, Lourenço Luis. Organização e administração do ministro do Império. Brasília: Funcep, 1984. (Coleção História Administrativa do Brasil).

LEAL, Victor Nunes. Coronelismo, enxada e voto. Rio de Janeiro: Nova Fronteira, 1997.

LIMA JÚNIOR, Olavo Brasil. As reformas administrativas no Brasil: modelos, sucessos e fracassos. Revista do Serviço Público, v. 49, n. 2, 1998. 
LINHARES, Maria Yedda (Org.). História geral do Brasil. Rio de Janeiro: Elsevier, 1990.

MACEDO, Roberto. História administrativa do Brasil. Brasília: Dasp, 1964.

MARCELINO, Gileno Fernandes. Evolução do Estado e reforma administrativa. Brasília: Sedap, 1987.

. Governo, imagem e sociedade. Brasília: Funcep, 1988.

. Em busca do Estado moderno: as reformas administrativas planejadas no Brasil. Revista Recursos Humanos, Brasília: Instituto de Recursos Humanos, ano I, n. 2, p. 39-44, 1993.

. Em busca da flexibilidade do Estado: o desafio das reformas planejadas no Brasil. Revista de Administração Pública, v. 37, n. 3, p. 641-659, 2003.

MARE. (Ministério da Administração e Reforma do Estado). Plano Diretor da Reforma do Aparelho do Estado. Brasília: Presidência da República, Imprensa Oficial, 1995.

MENDONÇA, Sonia Regina de. As bases do desenvolvimento capitalista dependente: da industrialização restringida à internacionalização. In: LINHARES, Maria Yeda. História geral do Brasil. Rio de Janeiro: Elsevier, 1990.

MOTTA, Paulo Roberto. Administração para o desenvolvimento: a disciplina em busca da relevância. Revista de Administração Pública, v. 4, n. 2, p. 7-45, 1972.

. Doutrinas de inovação em administração pública: a questão dos valores. In: MOTTA, Paulo R.; CARAVANTES, Geraldo R. Planejamento organizacional: dimensões sistêmico-gerenciais. Porto Alegre: DFRH/FGV, 1979. p. 153.

. Modernização administrativa: propostas alternativas para o Estado latinoamericano. Revista de Administração Pública, v. 21, n. 4, 1987.

NASCIMENTO, Kleber. Reflexões sobre estratégia de reforma administrativa: a experiência federal brasileira. Revista de Administração Pública, 1967.

OSBORNE, David; GAEBLER, Ted. Reinventando o governo: como o espírito empreendedor está transformando o setor público. Brasília: Enap, 1997.

PACHECO, Regina Sílvia. Regulação no Brasil: desenho das agências e formas de controle. Revista de Administração Pública, v. 40, n. 4, p. 523-543, 2006.

PAULA, Ana Paula. Por uma nova gestão pública: limites e potencialidades da experiência contemporânea. Rio de Janeiro: FGV, 2005.

PEIXOTO, João Paulo M. Ideologia, pragmatismo e reforma do Estado. In: PEIXOTO, João Paulo M. Reforma e modernização do Estado. Sobral: UVA, 2000. p. 71-108. 
PETRUCCI, Vera; SCHWARZ, Letícia (Orgs.). Administração pública gerencial: a reforma de 1995. Brasília: UnB/Enap, 1999.

PINHEIRO, Armando Castelar; OLIVEIRA FILHO, Luiz Chrysóstomo de. Privatização no Brasil: passado, planos e perspectivas. Brasília: Ipea, 1991.

; GIAMBIAGI, Fábio. As empresas estatais e o programa de privatização do governo Collor. Brasília: Ipea, 1992.

PINHEIRO, Paulo Sérgio; WILHEIM, Jorge; SACHS, Ignacy. Brasil: um século de transformações. São Paulo: Companhia das Letras, 2001.

PRADO JÚNIOR, Caio. Formação do Brasil contemporâneo. São Paulo: Braziliense, 1979.

RAMOS, Alberto Guerreiro. Administração e contexto brasileiro. Rio de Janeiro: FGV, 1983.

RIBEIRO, Sheila Maria Reis. Reforma do aparelho de Estado no Brasil: uma comparação entre as propostas dos anos 60 e 90. In: CONGRESO DEL CLAD. 7. Anais... Lisboa, 2002, p. 1-21.

SARAVIA, Enrique. Processo de privatização em Argentina y Brasil: consecuencias em materia de desempeño empresarial e mercado de trabajo. In: Reforma y democracia, Caracas: Clad, n. 4, 1995.

TAPAJÓS, Vicente. Organização política e administrativa do Império. Brasília, 1984. (Coleção História Administrativa do Brasil).

TAUNAY, Alfredo d'Escrangnolle. Organização política e administrativa do Império brasileiro. Brasília: Dasp, Centro de Documentação e Informática, 1984. (Coleção História Administrativa do Brasil).

TORRES, João Camilo Oliveira. Interpretação da realidade brasileira. Rio de Janeiro: José Olympio, 1973.

TORRES, Marcelo Douglas de Figueiredo. Estado, democracia e administração pública no Brasil. Rio de Janeiro: FGV, 2004.

URUGUAI, Visconde de. Ensaio sobre o direito administrativo. In: CARVALHO, José Murilo de. Visconde de Uruguai. São Paulo: Ed. 34, 2002.

VELLOSO, João Paulo Reis; ALBUQUERQUE, Roberto Cavalcanti (Orgs.). Governabilidade \& reformas. Rio de Janeiro: José Olympio, 1995.

VINHOSA, Francisco Luiz Teixeira. Brasil, sede da monarquia, Brasil reino - $2^{\mathrm{a}}$ parte. Brasília: Funcep, Fundação Centro de Formação do Servidor Público, 1984. (Coleção Administrativa do Brasil). 
WAHRLICH, Beatriz Marques de Souza. Reforma administrativa federal brasileira: passado e presente. Revista de Administração Pública, v. 8, p. 27-75, 1974.

. O governo provisório de 1930 e a reforma administrativa. Revista de Administração Pública, v. 9, n. 4, p. 5-68, 1975.

. Institucionalização da reforma administrativa: atuação do Conselho Federal de Serviço Público Civil e da comissão permanente de padronização (1936 a 1938). Revista de Administração Pública, v. 10, n. 4, p. 21-54, 1976.

. Desburocratização e desestatização: novas considerações sobre as prioridades brasileiras de reforma administrativa na década de 80. Revista de Administração Pública, v. 18, n. 4, p. 72-87, 1984.

WEHLING, Arno; WEHLING, Maria José C. M. Formação do Brasil colonial. Rio de Janeiro: Nova Fronteira, 1999.

WILCKEN, Patrick. Império à deriva. Rio de Janeiro: Objetiva, 2005. 